\title{
Evaluation of the GEM-AQ model in the context of the AQMEII Phase 1 project
}

\author{
J. Struzewska ${ }^{1}$, M. Zdunek ${ }^{1}$, J. W. Kaminski ${ }^{2,3}$, L. Lobocki ${ }^{1}$, M. Porebska ${ }^{1}$, M. Jefimow ${ }^{1}$, and L. Gawuc ${ }^{1}$ \\ ${ }^{1}$ Institute of Environmental Engineering, Warsaw University of Technology, Warsaw, Poland \\ ${ }^{2}$ EcoForecast Foundation, Warsaw, Poland \\ ${ }^{3}$ Centre for Research in Earth and Space Science, Lasonde School of Engineering, York University, Toronto, Ontario, Canada \\ Correspondence to: J. Struzewska (joanna.struzewska@is.pw.edu.pl)
}

Received: 29 July 2014 - Published in Atmos. Chem. Phys. Discuss.: 19 January 2015

Revised: 24 March 2015 - Accepted: 25 March 2015 - Published: 16 April 2015

\begin{abstract}
In the scope of the AQMEII Phase 1 project the GEM-AQ model was run over Europe for the year 2006. The modelling domain was defined using a global variable resolution grid with a rotated equator and uniform resolution of $0.2^{\circ} \times 0.2^{\circ}$ over the European continent. Spatial distribution and temporal variability of the GEM-AQ model results were analysed for surface ozone and $\mathrm{PM}_{10}$ concentrations. Model results were compared with measurements available in the ENSEMBLE database. Statistical measures were used to evaluate performance of the GEM-AQ model. The mean bias error, the mean absolute gross error and the Pearson correlation coefficient were calculated for the maximum $8 \mathrm{~h}$ running average ozone concentrations and daily mean $\mathrm{PM}_{10}$ concentrations. The GEM-AQ model performance was characterized for station types, European climatic regions and seasons. The best performance for ozone was obtained at suburban stations, and the worst performance was obtained for rural stations where the model tends to underestimate. The best results for $\mathrm{PM}_{10}$ were calculated for urban stations, while over most of Europe concentrations at rural sites were too high. Discrepancies between modelled and observed concentrations were discussed in the context of emission data uncertainty as well as the impact of large-scale dynamics and circulation of air masses. Presented analyses suggest that interpretation of modelling results is enhanced when regional climate characteristics are taken into consideration.
\end{abstract}

\section{Introduction}

The Air Quality Model Evaluation International Initiative (AQMEII; Galmarini et al., 2012) is a collaborative project aimed at improving our understanding of uncertainties and limitations of regional-scale air quality models. During Phase 1 of AQMEII, air quality simulations encompassing two domains, Europe and North America, were carried out for 2006. Several results of this initiative have already been published. Solazzo et al. (2012a) reported operational evaluation (Dennis et al., 2010) of particulate matter predictions by 10 models; this paper can serve as a general reference for the intercomparison methodology, data used and the participating models. Evaluation of ozone predictions was presented by Solazzo et al. (2012b). Appel et al. (2012) presented and discussed results obtained with the Community Multiscale Air Quality (CMAQ) model using different boundary conditions. Brandt et al. (2012) reported modelling results with the Danish Eulerian Hemispheric Model (DEHM). Pirovano et al. (2012) discussed differences in simulations with the Comprehensive Air Quality Model with Extensions (CAMx) and the CHIMERE model. CAMx predictions were discussed by Nopmongcol et al. (2012), while CMAQ simulations were done and analysed by Tagaris et al. (2013).

As a part of Phase 1 of the AQMEII project, a simulation of air quality in Europe was conducted using the Global Environmental Multiscale Air Quality model (GEMAQ, Kaminski et al., 2008). This model differs from other Phase 1 participating models in two aspects. First, it is a multiscale model that can cover the entire globe using a uniformly spaced latitude/longitude grid, a global variable reso- 
lution grid or a limited-area extent. Second, the atmospheric chemistry model is implemented online within the meteorological model, sharing the advection and subgrid transport schemes. As the GEM-AQ model was used in its global variable-resolution mode, this simulation required neither externally supplied meteorological fields nor lateral boundary conditions. The annual simulation presented here consisted of a series of daily runs, each initialized with a global meteorological objective analysis (Gauthier et al., 1999) using the 3D-Var assimilation method, and utilizing air quality results from the previous day as initial conditions for the air quality module. Results from the GEM-AQ model simulations were already used by Solazzo et al. (2013) to address diversity in multi-model ensembles.

In this paper we present a comprehensive operational evaluation of the GEM-AQ model. Concentrations of ozone and $\mathrm{PM}_{10}$ are compared with surface measurements.

The database of the AQMEII project contained hourly measurements of pollutant concentrations taken at rural, suburban and urban sites. Ozone concentrations were available from 472 rural, 391 suburban and 527 urban stations. For $\mathrm{PM}_{10}$ there were 119,110 and 263 stations, correspondingly. To address the possible representativeness issues pertinent to the spatial resolution adopted in the project, we shall present the results stratified according to the station types.

\section{Model description}

As the GEM-AQ model used in this study has been extensively documented elsewhere (Côté et al., 1998a, b; Mailhot et al., 2006; Kaminski et al., 2008; Gong et al., 2012), we shall focus on the model configuration choices used in this study. The meteorological component of the system, the GEM model, is a medium-range operational weather forecast model of the Canadian Meteorological Centre.

\subsection{Model formulation}

The GEM model used in this study solves the hydrostatic primitive equations cast in spherical coordinates (with a rotated equator plane in order to minimize distortions over the uniform resolution area), with a terrain-following, hybrid pressure-type vertical coordinate comprising 28 levels, of which 8 may fall into a well-developed boundary layer. The top of the model domain is located at $10 \mathrm{hPa}$, whereas the height of the lowest atmospheric level is approximately $40 \mathrm{~m}$. The model uses a semi-Lagrangian time discretization with a semi-implicit approximation of terms that give rise to fast gravitational modes (Robert, 1985) - a feature crucial for its multiscale applications as well as for integration using variable-resolution meshes. This scheme permits using time steps several times longer than in, for instance, a split-explicit method. With a few exceptions, choices of physical parameterizations made for this study follow the
$15 \mathrm{~km}$ version of the Canadian Regional Forecast System as documented by Mailhot et al. (2006). The turbulence parameterization is based on a turbulent kinetic energy budget with inclusion of statistical subgrid-scale cloudiness (Bélair et al., 2005) and the Bougeault-Lacarrere specification of the length scale (Bougeault and Lacarrere, 1989); surface energy budget is modelled with the force-restore equation (Deardorff, 1978). Gravity wave drag effects are taken into account using a modified McFarlane parameterization (McFarlane, 1987; McLandress and McFarlane, 1993). Condensation processes are handled with the Kain-Fritsch deep convection scheme (Kain and Fritsch, 1990, 1993), the so-called Kuotransient shallow convection parameterization (see Bélair et al., 2005) and the Sundqvist (Sundqvist, 1978) scheme for non-convective clouds. Solar and infrared radiation are modelled using Fouquart and Bonnel (1980) and Garand (1983) schemes, fully interactive with clouds.

The gas-phase chemistry package of GEM-AQ (Kaminski et al., 2008) describes 116 chemical and 19 photolysis reactions among 50 species or groups of species and is based on the second version of the Acid Deposition and Oxidation Model (Venkatram et al., 1988; Lurmann, 1986) with extensions for free-tropospheric chemistry. For a complete list of species and reactions, see Kaminski et al. (2008). A simplified aqueous-phase reaction module allows for oxidation of $\mathrm{SO}_{2}$ to sulphate. Aerosols are modelled with a sectional module CAM (Canadian Aerosol Module; Gong et al., 2003) with five aerosols types - sulphate, black carbon, organic carbon, sea-salt and soil dust - size-segregated into 12 logarithmically spaced bins. The aerosol module includes parameterizations of nucleation, condensation, coagulation, sedimentation and dry deposition, in-cloud oxidation of $\mathrm{SO}_{2}$ and scavenging and below-cloud scavenging of aerosol species by rain and snow.

\subsection{Model configuration}

For this study the GEM-AQ model was run on the global variable grid with rotated equator and with the resolution of $0.2^{\circ} \times 0.2^{\circ}$ over the European continent. The number of grid points was set to $288 \times 264$ on the globe and $197 \times 190$ in the core part (Fig. 1). In the vertical, 28 sigma-hybrid layers extending to $10 \mathrm{hPa}$ were used. The simulation was performed from 1 January to 31 December 2006, as a set of $30 \mathrm{~h}$ forecasts with a $6 \mathrm{~h}$ overlap. The integration time step of $600 \mathrm{~s}$ was used.

Emission data were prepared for the experiment by TNO (TNO, Utrecht, the Netherlands) using MACC (Monitoring Atmospheric Composition and Climate) methodology (Pouliot et al., 2012). Anthropogenic emissions included primary gaseous pollutants such as $\mathrm{O}_{2}, \mathrm{NO}_{\mathrm{x}}, \mathrm{CO}$, NMVOC, $\mathrm{NH}_{3}, \mathrm{CH}_{4}$ and particle pollution of the fine and coarse mode for individual SNAP (standardized nomenclature for air pollutants) sectors. Hourly biogenic emissions provided by the AQMEII project were used. Emissions outside the area pro- 


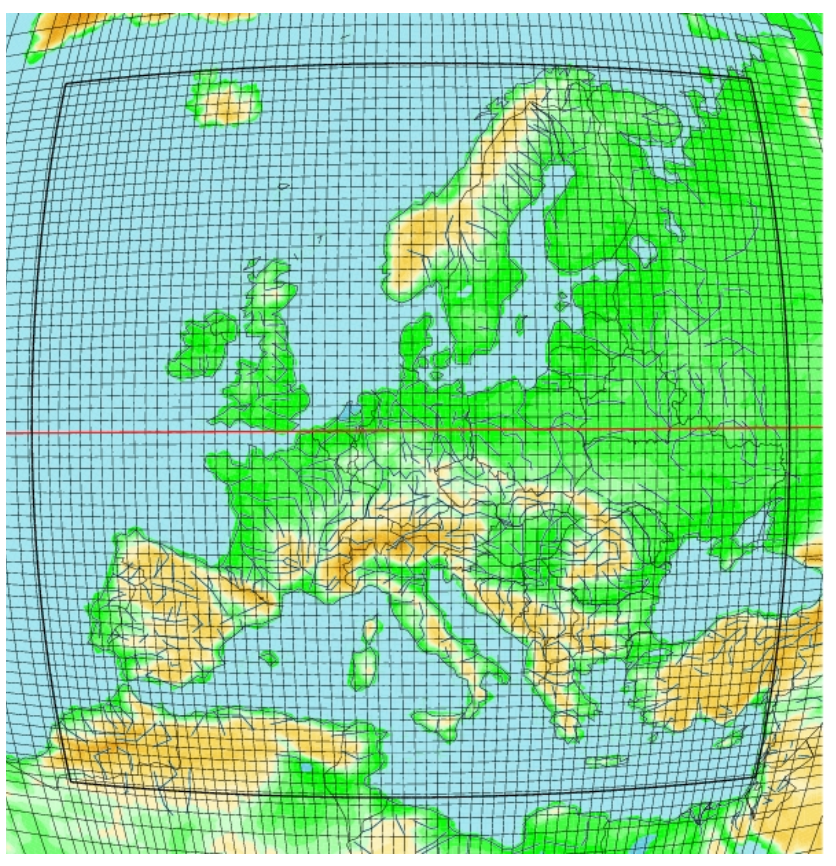

Figure 1. GEM-AQ computational domain configuration. Global variable grid with rotated equator (red line). Thicker black line borders the central region with the resolution of $0.2^{\circ} \times 0.2^{\circ}$.

vided by AQMEII were compiled using EDGAR 2.0 (Emission Database for Global Atmospheric Research, for 1990 base inventory year) and GEIA (Global Emissions Inventory Activity) global inventories (Olivier et al., 1999; Olivier and Berdowski, 2001). Anthropogenic emissions were distributed within the four lowest model layers (up to $\sim 630 \mathrm{~m}$ ) with different injection height profiles for each of the SNAP sectors. Temporal profiles modulating annual and diurnal variation of emission fluxes for each SNAP were used. Surface anthropogenic and biogenic emission fluxes were applied as a bottom boundary condition in the vertical diffusion equation.

\section{Modelling results}

Following the methodology used in previous publications describing the AQMEII Phase 1 results, the evaluation was undertaken with respect to station type (Hogrefe et al., 2013; Nopmongcol et al., 2012; Pirovano et al., 2012) and with respect to climatic differences between geographical regions in Europe (Solazzo et al., 2012a, b; Pirovano et al., 2012; Putaud et al., 2010). However, in contrast to previous publications, four different climatic regions were chosen in our analysis. The selected regions follow the Köppen climate classifications for Europe (Fig. 2). Region I is northern Europe, the Scandinavian Peninsula and Finland, reflecting boreal continental climate. Region II is western Europe, reflecting maritime climate with the influence of an inflow from

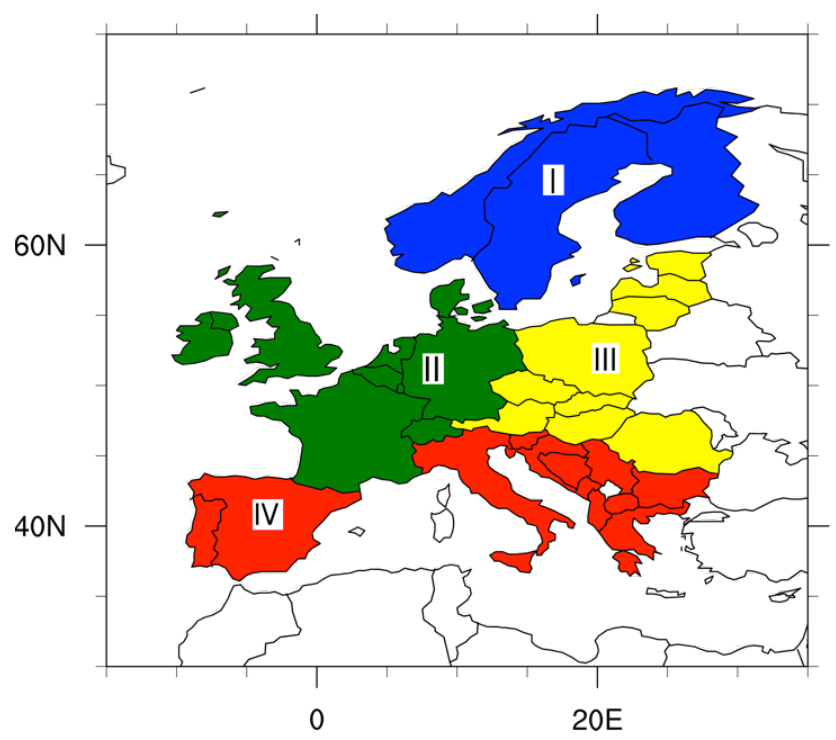

Figure 2. Regions selected for analysis of the GEM-AQ model results.

over the Atlantic Ocean. Region III is central and eastern Europe, characterized mainly by transitional and warm summer continental climate (some countries were not included, as observations were not available in the database used). Region IV covers regions with the Mediterranean climate.

The following statistical measures were used to evaluate performance of the GEM-AQ model: mean bias error (MBE), mean absolute gross error (MAGE) and the Pearson correlation coefficient.

\subsection{Ozone}

Analysis of ozone concentrations variability was based on daily maximum $8 \mathrm{~h}$ running average. Evaluation of the GEMAQ model performance was done for 1386 stations available in the ENSEMBLE database (Galmarini et al., 2001, 2004).

\subsubsection{Spatial distribution of ozone concentrations}

Spatial and temporal variability of the modelled ozone concentrations as well as the mean bias error with respect to the type of station (rural/suburban/urban) were assessed on a seasonal basis.

Spatial distribution of model data and model performance statistics for maximum $8 \mathrm{~h}$ running average ozone concentrations during winter months (DJF) and mean bias error for three types of stations is shown in Fig. 3. The calculated ozone concentration over most of Europe is in the range 40$50 \mu \mathrm{g} \mathrm{m}^{-3}$. Over the North Sea and the Baltic Sea concentrations are lower $\left(30-40 \mu \mathrm{g} \mathrm{m}^{-3}\right)$. Lowest ozone levels (below $30 \mu \mathrm{g} \mathrm{m}^{-3}$ ) were calculated over regions characterized by high $\mathrm{NO}_{\mathrm{x}}$ emission (i.e. Benelux, the Po Valley, London, Paris). Concentrations higher than $50 \mu \mathrm{g} \mathrm{m}^{-3}$ are modelled 
in southern Europe, with the maximum (up to $70 \mu \mathrm{g} \mathrm{m}^{-3}$ ) in mountain regions (the Alps, eastern part of the Carpathian Mountains, Pyrenees, Balkan Mountains).

During the winter (DJF) MBE for most of the rural stations varies in the range of $-10 \div 10 \mu \mathrm{g} \mathrm{m}^{-3}$. Over Scandinavia and the British Isles the underestimation is higher, up to $-20 \mu \mathrm{g} \mathrm{m}^{-3}$. Measurements at rural stations located in the Alps are higher than modelled results. Suburban stations (available for the analysis) are located mainly in western Europe. For most of these stations the bias is small and positive, in the range of 0 to $10 \mu \mathrm{g} \mathrm{m}^{-3}$. However, in the mountain regions the bias is up to $30 \mu \mathrm{g} \mathrm{m}^{-3}$. Spatial coverage is most complete in western Europe for urban stations. At most of the sites the bias is positive and small, in the range of 0 $10 \mu \mathrm{g} \mathrm{m}^{-3}$. The model underestimated ozone concentrations for a few stations located in Scandinavia and overestimated up to $30-40 \mu \mathrm{g} \mathrm{m}^{-3}$ over industrial regions in Europe (i.e. southern Italy, south-eastern and northern France, the Ruhr region, Silesia, the Moravian Gate). In the same region in northern Spain the model underestimated ozone concentration levels for rural sites and overestimated for urban stations.

Spatial distribution of ozone concentrations and MBE for the spring (MAM) are shown in Fig. 4. Over most of Europe the maximum $8 \mathrm{~h}$ running average ozone concentrations were in the range of 80 to $100 \mu \mathrm{g} \mathrm{m}^{-3}$. Over Scandinavia and the British Isles, ozone concentrations were below $70 \mu \mathrm{g} \mathrm{m}^{-3}$. Ozone concentrations higher than $100 \mu \mathrm{g} \mathrm{m}^{-3}$ were calculated in mountain regions in south-eastern Europe (the Apennine mountains) and in the Alps. In western and central Europe, elevated ozone concentrations were over industrial areas (i.e. Silesia and the Moravian Gate). MBE at rural stations is generally smaller than in winter months. For most sites the error is in the range of $-10 / 10 \mu \mathrm{g} \mathrm{m}^{-3}$. In central Europe and the British Isles the discrepancies were reduced as compared to the winter months, while in Scandinavia the underestimation is larger, especially near the Baltic Sea coast. In the Alps the overestimation is smaller than in the winter months. For suburban stations the model performance is good. The underestimation of modelled results is mainly in coastal areas. In most of the urban sites the model overestimates ozone levels up to $20 \mu \mathrm{g} \mathrm{m}^{-3}$ while the underestimation occurred at the costal stations.

Summer (JJA) modelled ozone concentrations (Fig. 5) show uniform distribution in the range of 90 to $100 \mu \mathrm{g} \mathrm{m}^{-3}$ in western and eastern Europe. Lower concentrations over Scandinavia are due to lower solar irradiance, lower temperature and lower emissions of ozone precursors. Over the south-eastern part of the British Isles, concentrations over $80 \mathrm{\mu g} \mathrm{m}^{-3}$ were calculated. The highest concentrations (over $120 \mathrm{\mu g} \mathrm{m}^{-3}$ ) were calculated over the Po Valley and the Iberian Peninsula. Ozone concentration over the Atlantic Ocean is lower than in spring months, with values below $60 \mu \mathrm{g} \mathrm{m}^{-3}$.

During summer months (JJA) the distribution of MBE for rural stations shows underestimation over the British
Isles and the Iberian Peninsula larger than in spring months $\left(-20\right.$ to $\left.-10 \mu \mathrm{g} \mathrm{m}^{-3}\right)$. In Scandinavia and central Europe, modelled concentrations better agree with observed values. In south-eastern Europe the model tends to overestimate observed concentrations. The model tends to overestimate ozone concentrations as compared to observations at suburban stations. In western and central Europe, MBE is in the range of -10 to $10 \mu \mathrm{g} \mathrm{m}^{-3}$, with highest values over the Benelux and industrial regions on the border of France and Germany. Over the Iberian Peninsula the model underestimates ozone concentrations. MBE calculated for urban stations is in most cases positive. However, MBE is significantly reduced as compared to winter and spring months.

The distribution of ozone concentrations in the autumn is shown in Fig. 6. Over most of Europe the ozone concentrations exceed $60 \mu^{-3} \mathrm{~m}^{-3}$. Lower concentrations were calculated near the British Isles, the North Sea, Scandinavia and eastern Europe. The highest concentrations over $80 \mu \mathrm{g} \mathrm{m}^{-3}$ are modelled in mountain regions in the southern part of the continent. Ozone concentrations below $40 \mu \mathrm{g} \mathrm{m}^{-3}$ were calculated in south-eastern Europe.

In autumn (SON) for most rural stations MBE is positive, in the range of 0 to $10 \mu \mathrm{g} \mathrm{m}^{-3}$. Underestimation was up to $-10 \mu \mathrm{g} \mathrm{m}^{-3}$ over Scandinavia and the British Isles and over the Iberian Peninsula. Significant overestimation was calculated in the Alps (up to $30 \mu \mathrm{g} \mathrm{m}^{3}$ ). Positive bias was in the range of 10 to $20 \mu \mathrm{g} \mathrm{m}^{-3}$ over the industrial regions along the border of Germany and France and over the Netherlands. For urban and suburban stations the spatial distribution of MBE is similar. Bias is positive in the range of 0 to $20 \mu \mathrm{g} \mathrm{m}^{-3}$. The highest error values were calculated in the Alps.

\subsubsection{Temporal variability of ozone concentrations}

In order to study the model performance on a daily basis, maximum $8 \mathrm{~h}$ running average concentrations were calculated and averaged over stations in four regions of the European continent characterized with different climatological conditions: western Europe, northern Europe, central and eastern Europe and southern Europe (Figs. 7-14).

In northern Europe there were only 45 stations available for the comparison. The model shows systematic underestimation during the autumn, winter and spring: MBE is $-16.8 \mu \mathrm{g} \mathrm{m}^{-3}$ and MAGE is $20.7 \mu \mathrm{g} \mathrm{m}^{-3}$. The differences between modelled and observed concentration values are much smaller from June to September (Fig. 7). In contrast to other regions where highest concentrations were observed from May to July, in this region the period with the highest concentrations, exceeding $100 \mu \mathrm{g} \mathrm{m}^{-3}$, was observed at the end of April and the beginning of May, while during the summer months there were two high-concentration episodes. In spite of the systematic bias, the correlation coefficient is 0.83 , which shows good agreement in terms of changes related to exchange of air masses. A scatter plot representing 
a)

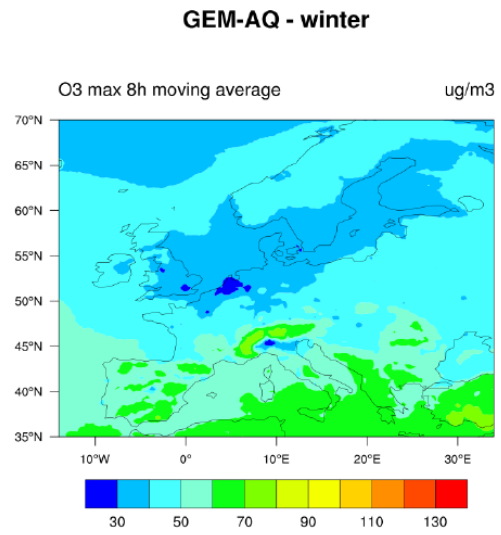

c)

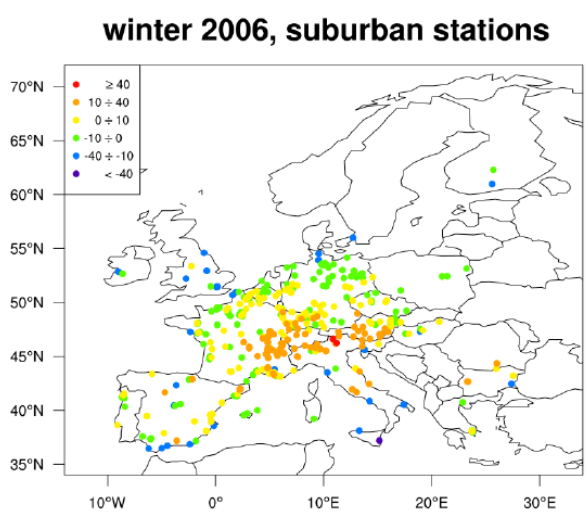

b)

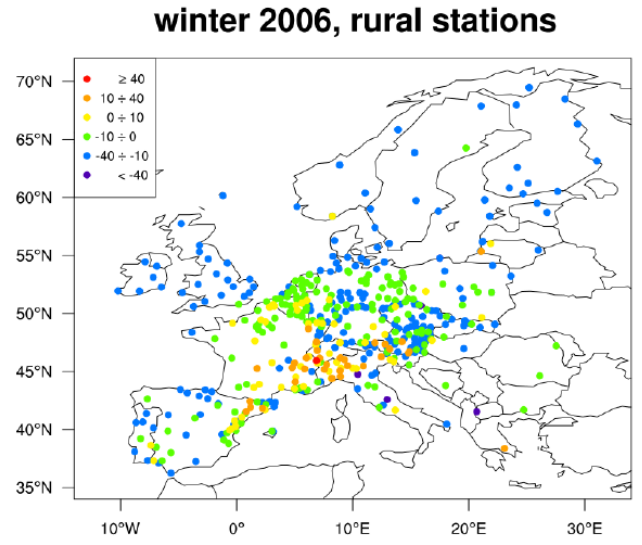

d)

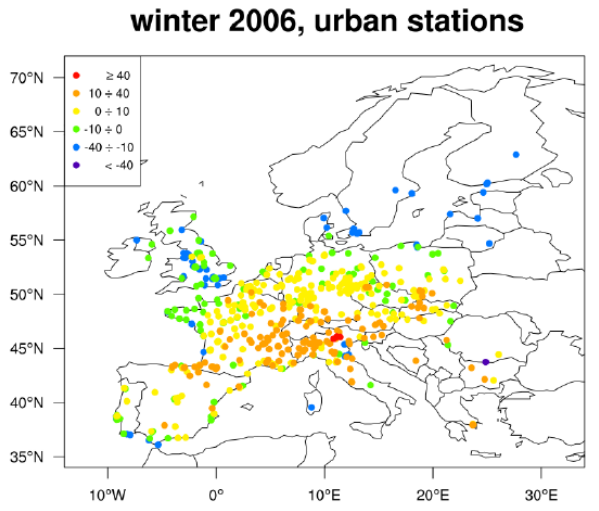

Figure 3. Winter (DJF) maximum $8 \mathrm{~h}$ running average ozone concentration in $\mu \mathrm{g} \mathrm{m}^{-3}$ (a), MBE at rural stations (b), MBE at suburban stations (c) and MBE at urban stations (d).

concentrations averaged over days (Fig. 8) shows that levels in the range 60-80 were reproduced best.

In western Europe the agreement between model and observations was analysed for 791 stations. Temporal variability of the maximum $8 \mathrm{~h}$ running average ozone concentrations was captured very well: MBE is low at $-0.4 \mu \mathrm{g} \mathrm{m}^{-3}$ and MAGE is $16.5 \mu \mathrm{g} \mathrm{m}^{-3}$. Small overestimations were calculated in January, March, September and October. High concentrations were observed in June and July (Fig. 9). Three high-concentration episodes can be distinguished. During episodes, the model underestimated peak values by $\sim 20 \mu \mathrm{g} \mathrm{m}^{-3}$.

Short-term variability is reproduced correctly and the correlation coefficient is 0.91 . Scatter plots show that major discrepancies are for the highest concentrations during summer episodes $\left(>100 \mu \mathrm{g} \mathrm{m}^{-3}\right)$ (Fig. 10).
Analysis of the ozone concentrations variability in central Europe was undertaken for 251 stations. The model underestimated concentrations in March and April and during summer episodes (Fig. 11). MBE was $-1.5 \mu \mathrm{g} \mathrm{m}^{-3}$ and MAGE $17.6 \mu \mathrm{g} \mathrm{m}^{-3}$. The first period with exceptionally high concentrations was at the beginning of May and was not reproduced by the model. Rapid increase of ozone concentrations in central and eastern Europe was connected with the inflow of aerosols from biomass fires in eastern Europe, which plausibly contributed to changes of photodissociation rates. Other periods with high concentrations were caused by meteorological conditions favouring ozone production, and the increased ozone levels were captured by the model; however, modelled peak values were lower than observed. The value of the correlation coefficient is 0.89 . The scatter plots show slightly larger variation than over western Europe. The model tends to underpredict concentrations lower 
a)

GEM-AQ - spring

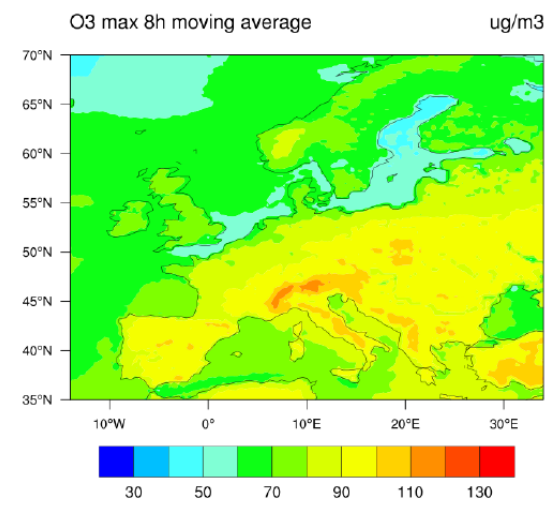

c)

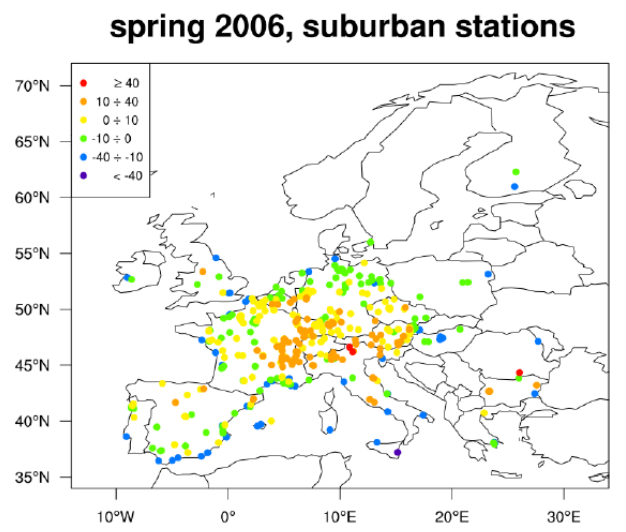

b)

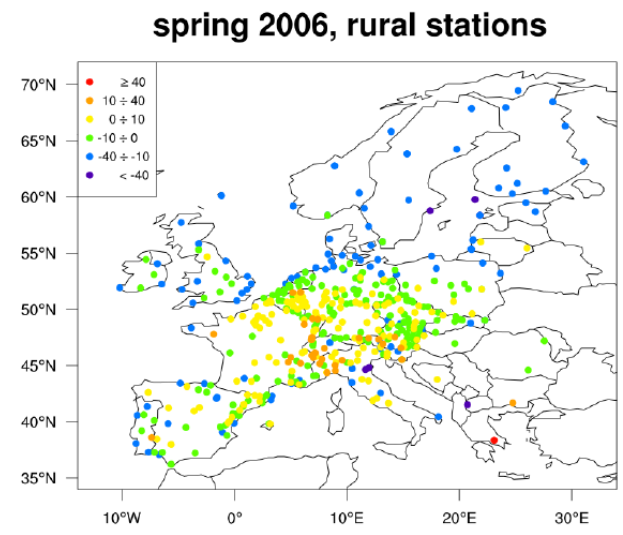

d)

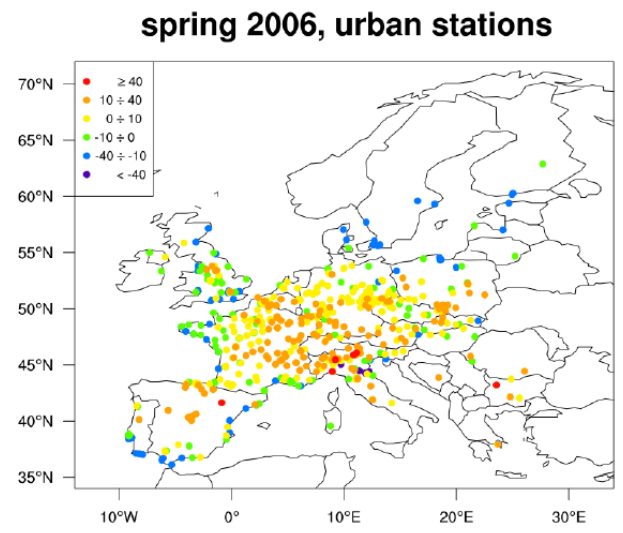

Figure 4. Spring (MAM) maximum $8 \mathrm{~h}$ running average ozone concentration in $\mu \mathrm{g} \mathrm{m}^{-3}$ (a), MBE at rural stations (b), MBE at suburban stations (c) and MBE at urban stations (d).

than $60 \mu \mathrm{g} \mathrm{m}^{-3}$ and higher than $100 \mu \mathrm{g} \mathrm{m}^{-3}$, while concentrations in the range $80-100 \mu \mathrm{g} \mathrm{m}^{-3}$ are in general overpredicted (Fig. 12).

In southern Europe measurements from 303 stations were available for the comparison. The short-term variability is reproduced well and the correlation coefficient is 0.96. During most of the year, modelled ozone levels show low negative bias $-1.4 \mu \mathrm{g} \mathrm{m}^{-3}$ that is due to underestimation of ozone concentrations in June, July and August (Fig. 13). Although concentration increase during episodes was consistent with observed variability, maximum values were $20-40 \mu \mathrm{g} \mathrm{m}^{-3}$ lower than observed. Even though MAGE is $19.9 \mu \mathrm{g} \mathrm{m}^{-3}$, the scatter plot for stations located in southern Europe shows the best linear fit (Fig. 14). Scatter plots presenting annual average concentrations indicate that, for observation at sites characterized with highest concentrations (above $100 \mu \mathrm{g} \mathrm{m}^{-3}$ ), the model underestimated ozone levels.

\section{2 $\quad \mathrm{PM}_{10}$}

The analysis of model performance was undertaken for 492 stations available in the ENSEMBLE database for $\mathrm{PM}_{10}$ concentration. The $24 \mathrm{~h}$ averages were calculated based on hourly measurements and model results.

\subsubsection{Spatial distribution of $\mathbf{P M}_{10}$ concentrations}

The pattern of modelled daily averaged $\mathrm{PM}_{10}$ concentrations during winter months (DJF) and spatial distribution of the mean bias error for different types of stations is shown in Fig. 15. The calculated $\mathrm{PM}_{10}$ concentrations over central and south-eastern Europe are in the range of $40-60 \mu \mathrm{g} \mathrm{m}^{-3}$. Over the rest of the continent, concentrations are lower below $30 \mu \mathrm{g} \mathrm{m}^{-3}$. The highest $\mathrm{PM}_{10}$ concentrations above $60 \mu \mathrm{g} \mathrm{m}^{-3}$ are modelled over Romania and the eastern part of Germany, with a maximum of up to $70 \mu \mathrm{g} \mathrm{m}^{-3}$. 
a)

GEM-AQ - summer

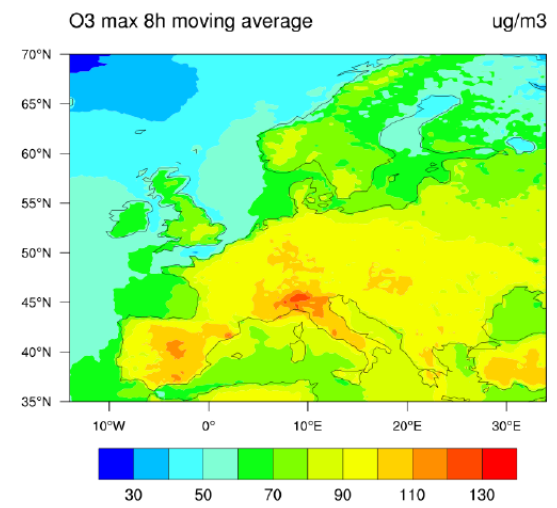

c)

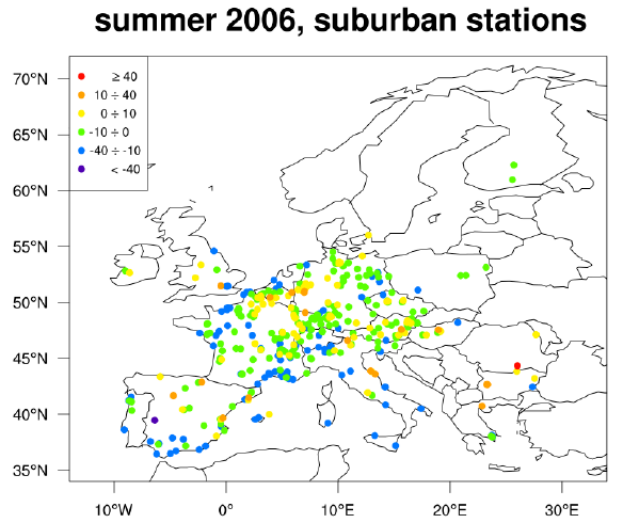

b)

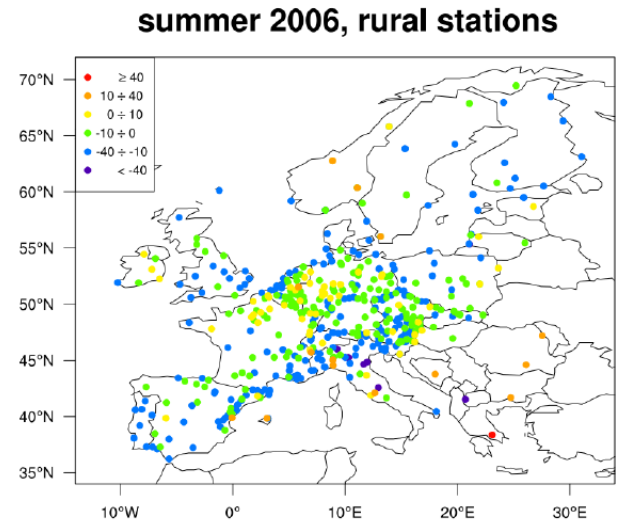

d)

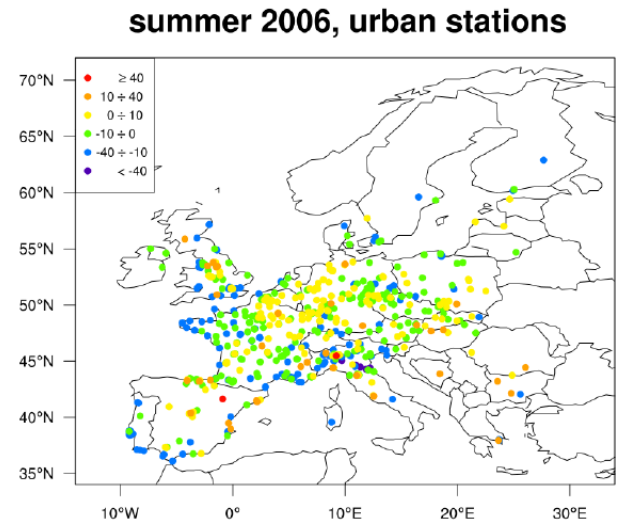

Figure 5. Summer (JJA) maximum $8 \mathrm{~h}$ running average ozone concentration in $\mu \mathrm{g} \mathrm{m}^{-3}$ (a), MBE at rural stations (b), MBE at suburban stations (c) and MBE at urban stations (d).

MBE for most rural stations is positive and high - up to $30 \mu \mathrm{g} \mathrm{m}^{-3}$. However, it should be noted that the rural stations available for the comparison are located mainly in Germany, the Czech Republic and Benelux. The overestimation was in Germany and the Czech Republic, while in Benelux, British Isles and Spain the model performs quite well. The highest overestimation is modelled over the eastern part of Germany for suburban stations. In central and western Europe the model performs well, while in Spain $\mathrm{PM}_{10}$ levels were underestimated up to $20 \mu \mathrm{g} \mathrm{m}^{-3}$. Spatial coverage of urban monitoring sites is more complete. For stations located in Germany and the Czech Republic the model overestimated $\mathrm{PM}_{10}$ levels. However, in central and southern Europe the model results are lower than the observed concentrations.

Spatial distribution of daily average $\mathrm{PM}_{10}$ concentrations and MBE for the spring (MAM) is shown in Fig. 16. Over most of Europe the maximum $24 \mathrm{~h} \mathrm{PM}_{10}$ concentrations were low - in the range of $15-30 \mu \mathrm{g} \mathrm{m}^{-3}$. The highest concentrations were calculated over central Europe, with maximum values over Poland and the eastern part of Germany. $\mathrm{PM}_{10}$ concentrations lower than $10 \mu \mathrm{g} \mathrm{m}^{-3}$ were modelled over Scandinavia and over the south-western part of the continent.

The distribution of MBE at rural stations shows good agreement over most of Europe, in spite of overestimations over the Czech Republic and Germany. For most of the suburban monitoring sites, MBE was lower than $10 \mu \mathrm{g} \mathrm{m}^{-3}$, except for eastern Germany where the model tends to overestimate and for some stations in Spain where modelled $\mathrm{PM}_{10}$ concentrations were lower than observed. For urban stations the pattern of MBE spatial distribution was similar to MBE calculated at suburban stations. MBE varies in a range of -10 to $10 \mu \mathrm{g} \mathrm{m}^{-3}$.

Summer (JJA) $\mathrm{PM}_{10}$ concentrations (Fig. 17) show uniform distribution in the range of $20-30 \mu \mathrm{g} \mathrm{m}^{-3}$ in western 
a)

GEM-AQ - autumn

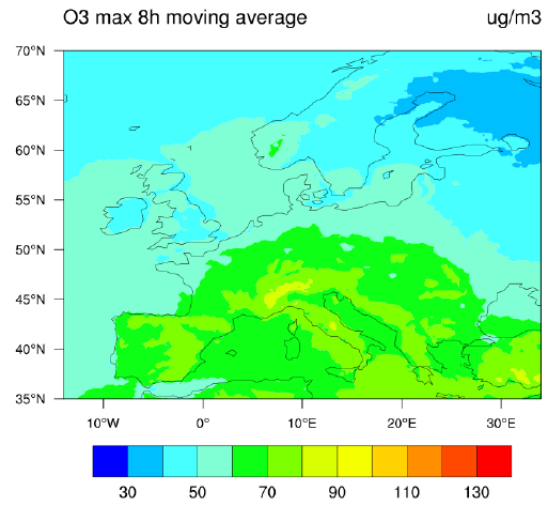

c)

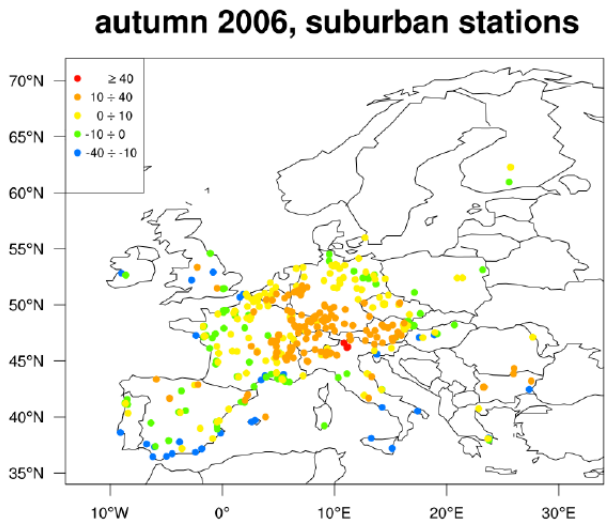

b)

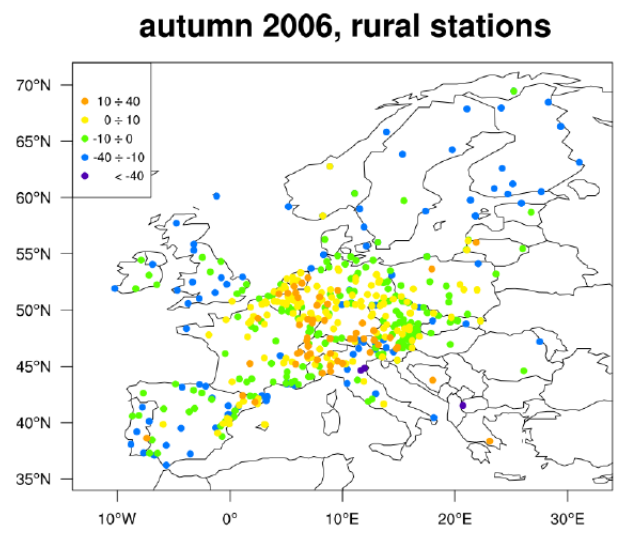

d)

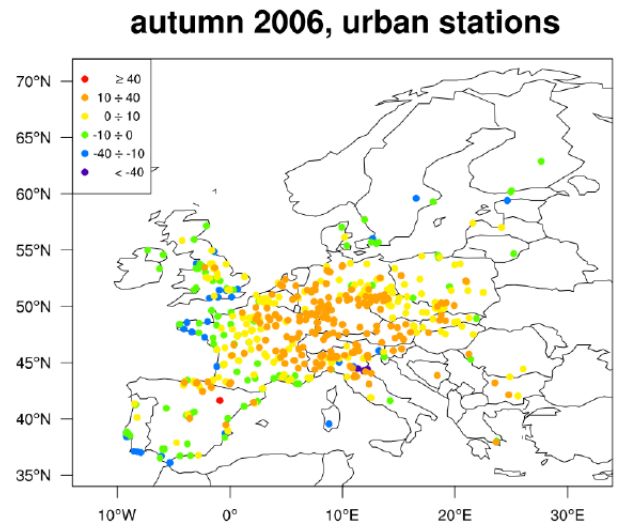

Figure 6. Autumn (SON) maximum $8 \mathrm{~h}$ running average ozone concentration in $\mu \mathrm{g} \mathrm{m}^{-3}$ (a), MBE at rural stations (b), MBE at suburban stations (c) and MBE at urban stations (d).

and eastern Europe. Lower concentrations (below $20 \mu \mathrm{g} \mathrm{m}{ }^{3}$ ) were calculated over Scotland, Scandinavia and northeastern Europe. The highest concentrations above $30 \mu \mathrm{g} \mathrm{m}^{-3}$ were calculated over central Europe, with the maximum over the eastern part of Germany. MBE distribution for all types of stations shows a similar pattern. Over Germany the model overestimates $\mathrm{PM}_{10}$ levels, while over Spain the model underestimated mainly for suburban sites. Over the rest of the continent the modelled and observed $\mathrm{PM}_{10}$ concentrations agree well, with small positive bias lower than $10 \mu \mathrm{g} \mathrm{m}^{-3}$.

The distribution of $\mathrm{PM}_{10}$ concentrations in autumn (SON) is shown in Fig. 18. The maximum $24 \mathrm{~h}$ averaged $\mathrm{PM}_{10}$ concentrations were in the range of 20 to $40 \mu \mathrm{g} \mathrm{m}^{-3}$ over most of Europe. As in other periods, highest concentrations were calculated over central Europe, with maximum values exceeding $60 \mu \mathrm{g} \mathrm{m}^{-3}$ over the eastern part of Germany. The lowest modelled $\mathrm{PM}_{10}$ concentrations (lower than $20 \mu \mathrm{g} \mathrm{m}^{-3}$ ) occur over Scandinavia and over the south-western part of the continent.

MBE distribution is similar to that in winter. MBE for rural stations is positive and shows highest discrepancies over the eastern part of Germany. For urban and suburban stations the overestimation of $\mathrm{PM}_{10}$ levels occurs over Germany, Czech and industrial regions in Poland. In western Europe the agreement is better, with MBE below $10 \mu \mathrm{g} \mathrm{m}^{-3}$. MBE over the Iberian Peninsula varies in the range of -20 to $10 \mu \mathrm{g} \mathrm{m}^{-3}$.

\subsubsection{Temporal variability of $\mathbf{P M}_{10}$}

A detailed analysis of the temporal variability was undertaken for four climatological regions in Europe. In northern Europe (for 19 stations) the model overestimated concentrations in January, while in February and March the agreement 


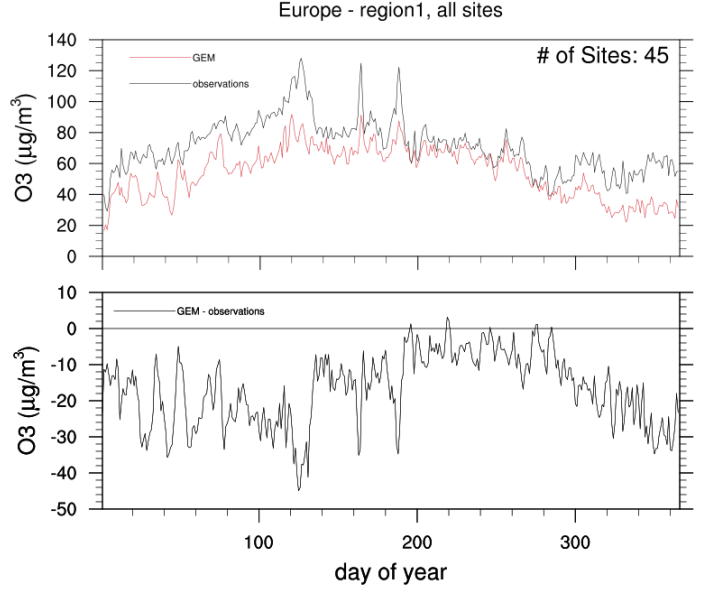

Figure 7. Time series of observed and modelled maximum $8 \mathrm{~h}$ running averaged ozone concentration averaged for all stations in northern Europe and MBE.

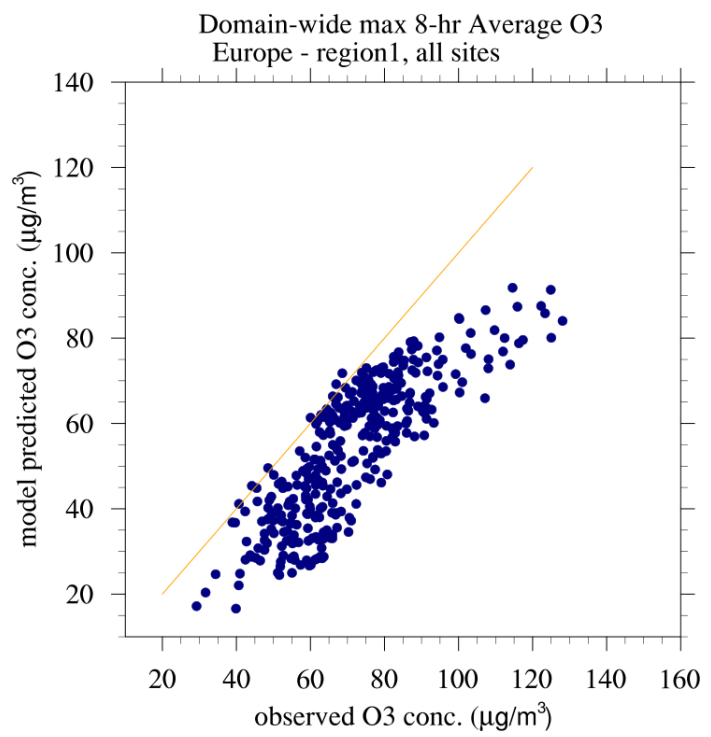

Figure 8. Scatter plot of maximum $8 \mathrm{~h}$ running average ozone concentration in northern Europe.

between model and observations was good. In April and the beginning of May there was an episode of elevated $\mathrm{PM}_{10}$ concentrations which was not captured by the model. Until mid-August, observed and modelled $\mathrm{PM}_{10}$ levels agree well. In autumn the model tends to overestimate on average 5$10 \mu \mathrm{g} \mathrm{m}^{-3}$. Although the modelled concentrations reflect observed values with MBE $0.6 \mu \mathrm{g} \mathrm{m}^{-3}$ and MAGE $10.3 \mu \mathrm{g} \mathrm{m}^{-3}$, the short- and mid-term variability was reproduced only during some months and the correlation coefficient is 0.32 .

In western Europe the agreement between model and observations was analysed for 251 stations. Temporal variability of $24 \mathrm{~h}$ average $\mathrm{PM}_{10}$ concentrations was captured very well, with a correlation coefficient of 0.73 . However,

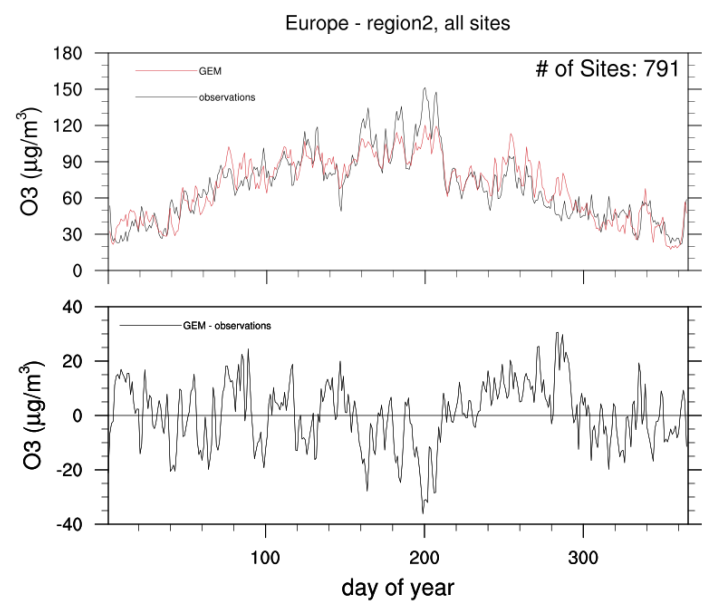

Figure 9. Time series of observed and modelled maximum $8 \mathrm{~h}$ running averaged ozone concentration averaged for all stations in western Europe and MBE.

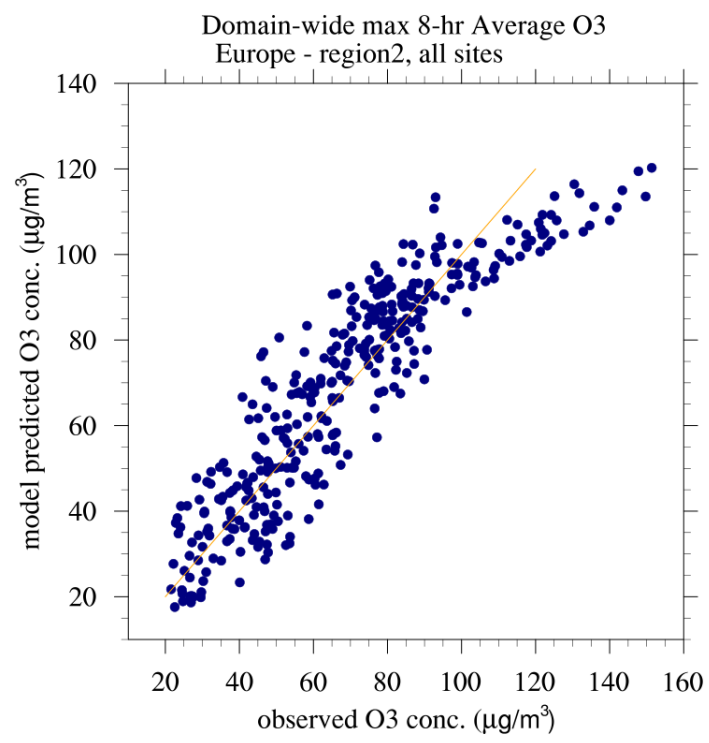

Figure 10. Scatter plot of maximum $8 \mathrm{~h}$ running average ozone concentration in western Europe.

the model tends to overestimate $\mathrm{PM}_{10}$ concentrations for all seasons - MBE is $8.9 \mu \mathrm{g} \mathrm{m}^{-3}$ and MAGE $16.7 \mu \mathrm{g} \mathrm{m}^{-3}$. The highest overestimation was modelled during autumn and winter months: January, February, October and December. The best agreement between modelled and observed $\mathrm{PM}_{10}$ concentrations was in spring months, while there was a small systematic overestimation $\sim 10 \mu \mathrm{g} \mathrm{m}^{-3}$ in summer.

In central Europe, 129 stations were available for the comparison. The model underestimated concentrations during severe episodes in January and the beginning of February. In spring, observed $\mathrm{PM}_{10}$ concentrations are reproduced correctly by the model. From June there is a small systematic overestimation averaging 10 to $15 \mu \mathrm{g} \mathrm{m}^{-3}$. During the last 

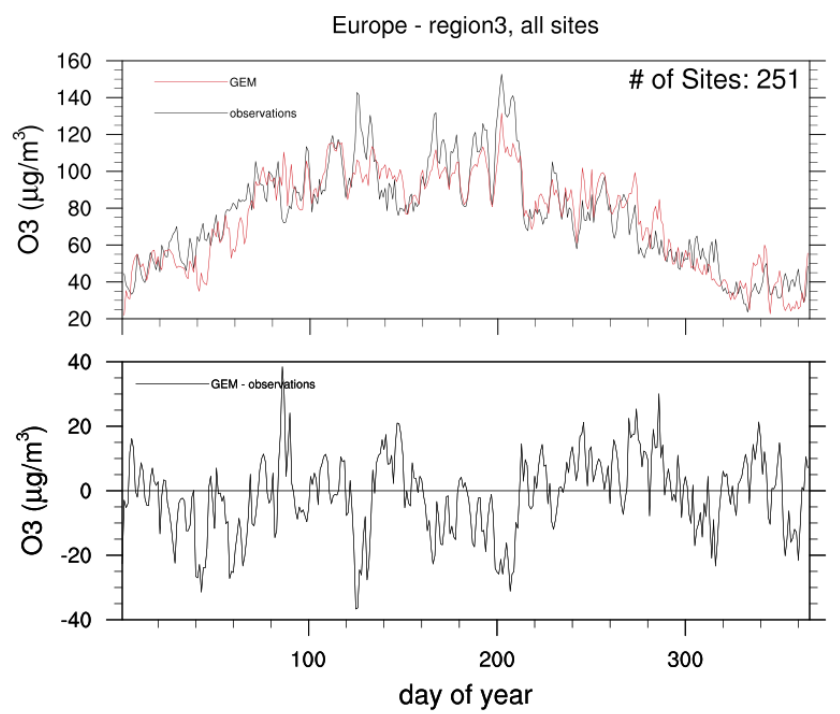

Figure 11. Time series of observed and modelled maximum $8 \mathrm{~h}$ running averaged ozone concentration averaged for (a) all stations in central Europe and (b) MBE.

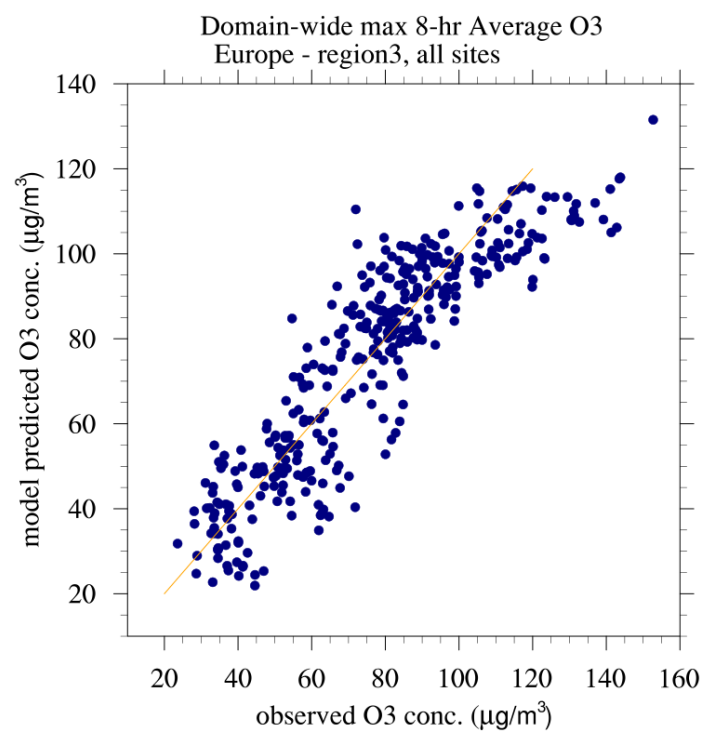

Figure 12. Scatter plot of maximum $8 \mathrm{~h}$ running average ozone concentration in central Europe.

quarter of the year the model overestimated $\mathrm{PM}_{10}$ concentrations: MBE was $5.9 \mu \mathrm{g} \mathrm{m}^{-3}$, MAGE $24.2 \mu \mathrm{g} \mathrm{m}^{-3}$ and the correlation coefficient was 0.72 . Overall variability of $\mathrm{PM}_{10}$ levels was captured. However, the model overestimated up to $30 \mu \mathrm{g} \mathrm{m}^{-3}$ during three periods in October, November and December that were not supported by observations.

In southern Europe, analysis was undertaken for 93 stations. The temporal variability is not reproduced by the model. However, some incidental agreement leads to the correlation coefficient of 0.56 . The negative bias $-9.4 \mu \mathrm{g} \mathrm{m}^{-3}$ is due to the underestimation of $\mathrm{PM}_{10}$ levels (Fig. 22), with

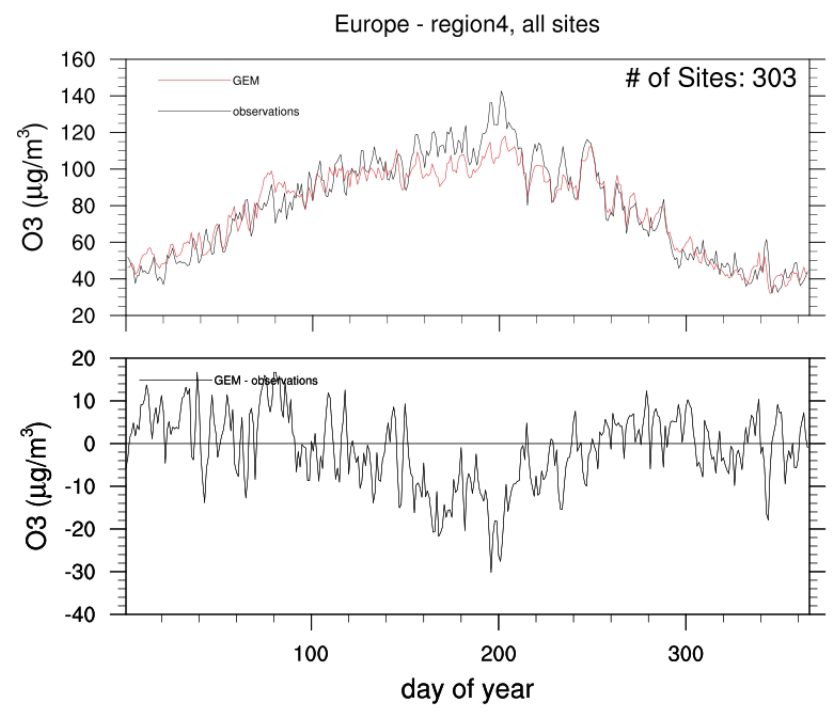

Figure 13. Time series of observed and modelled maximum $8 \mathrm{~h}$ running averaged ozone concentration averaged for (a) all stations in southern Europe and (b) MBE.

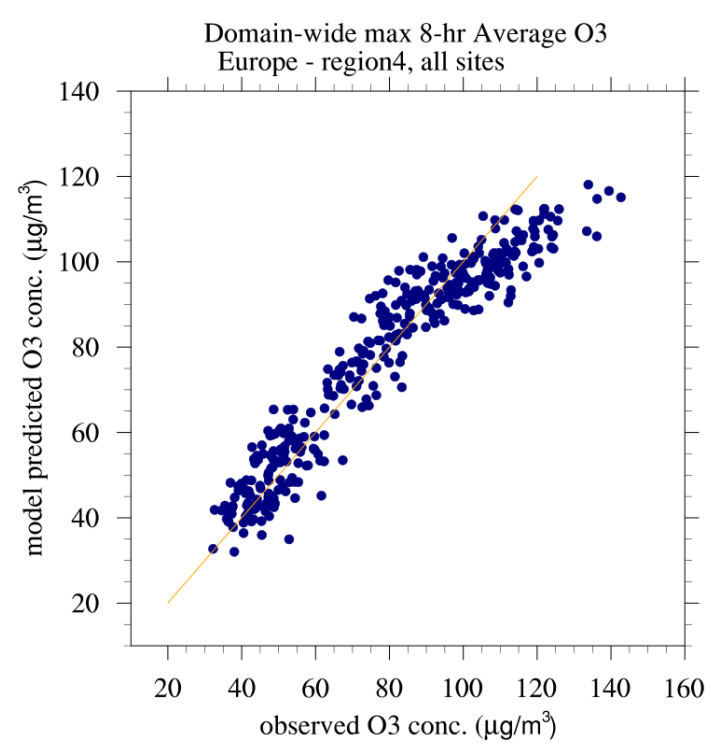

Figure 14. Scatter plot of maximum $8 \mathrm{~h}$ running average ozone concentration in central Europe.

MAGE $16.2 \mu \mathrm{g} \mathrm{m}^{-3}$. Overall modelled $\mathrm{PM}_{10}$ levels are lower than observed. The model overestimated only during a singe episode at the end of May.

\section{Discussion}

Spatial and temporal averaging is a common methodology used in model performance analysis for long-term simulations. However, it is clear that the averaging leads to error compensation and does not reflect the model's ability to re- 
a)

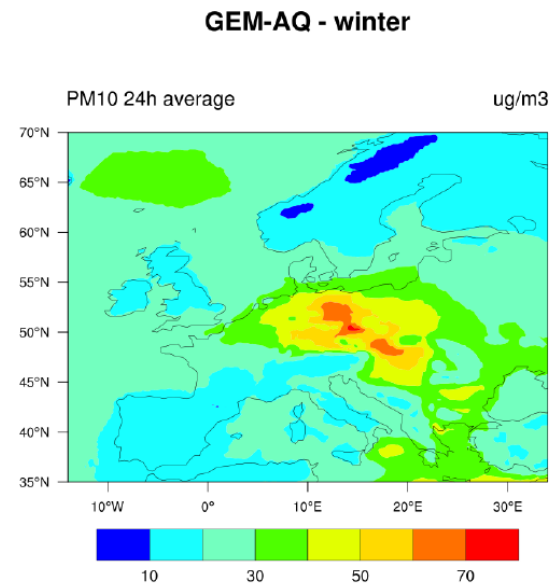

c)

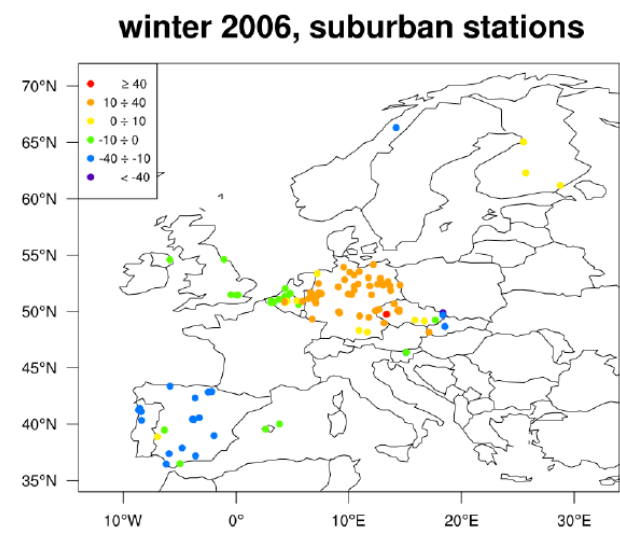

b)

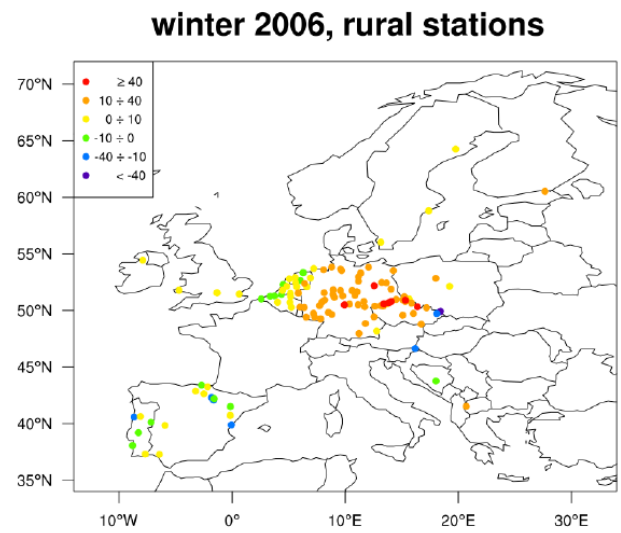

d)

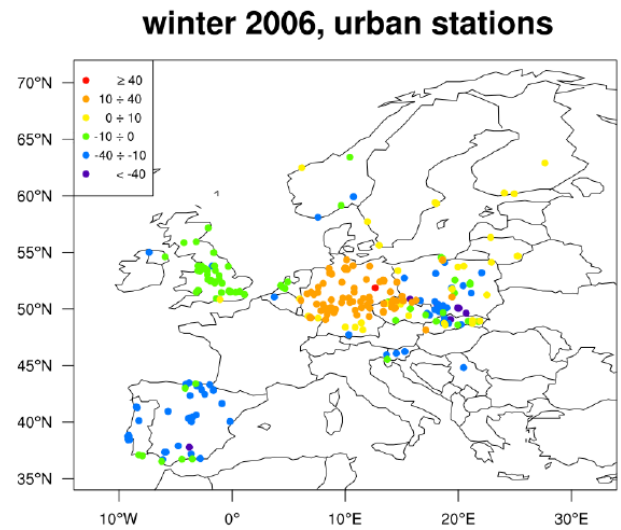

Figure 15. Winter (DJF) $24 \mathrm{~h}$ average $\mathrm{PM}_{10}$ concentrations in $\mu \mathrm{g} \mathrm{m}^{-3}$ (a), MBE at rural stations (b), MBE at suburban stations (c) and MBE at urban stations (d).

produce specific features of concentrations distribution. The choice of the averaging period (e.g. month, seasonal, annual) impacts the value of the bias error. Also, similar "average performance" might be obtained for cases with small systematic errors and large positive and negative errors.

\subsection{Ozone}

For rural background stations (472 sites) the GEM-AQ model underestimated ozone concentrations during the cold season (January-mid-March and November-December). During the summer, underestimation of peak values ranges from 30 to $40 \mu \mathrm{g} \mathrm{m}^{-3}$. Although the correlation coefficient is high (0.92), MBE is $-7 \mu \mathrm{g} \mathrm{m}^{-3}$ and MAGE is $18 \mu \mathrm{g} \mathrm{m}^{-3}$ (Table 1). For suburban (391 sites) and urban stations (527 sites), the characteristics of variability range and agreement with measurement is comparable. In January, March, Septem- ber and October the model slightly overestimated ozone concentrations. In June and July during pollution episodes, modelled concentrations are lower than observed by 10 to $20 \mu \mathrm{g} \mathrm{m}^{-3}$. Results for other months show very good agreement in terms of average concentration levels and short-term variability, which is confirmed with a very high correlation coefficient -0.93 for both types of stations. MBE is positive for suburban stations $\left(1.9 \mu \mathrm{g} \mathrm{m}^{-3}\right)$ and for urban stations $\left(2.5 \mu \mathrm{g} \mathrm{m}^{-3}\right)$, with MAGE 17.2 and $17.4 \mu \mathrm{g} \mathrm{m}^{-3}$ respectively. In contrast to Hogrefe et al. (2013), who reported higher correlation coefficient for ozone concentrations for rural sites than for "locally influenced sites", the GEM-AQ model performance in terms of the Pearson correlation coefficient was almost at the same level for all types of stations ( 0.92 for rural sites, 0.93 for suburban and urban sites).

The evaluation results reported by Pirovano et al. (2012) for CAMx and CHIMERE models showed that for both mod- 
a)

GEM-AQ - spring

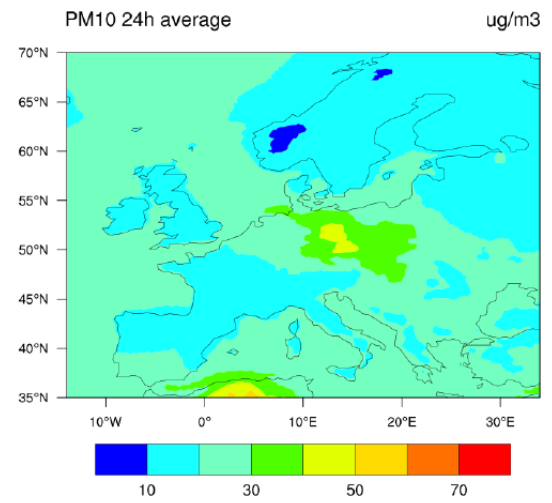

c)

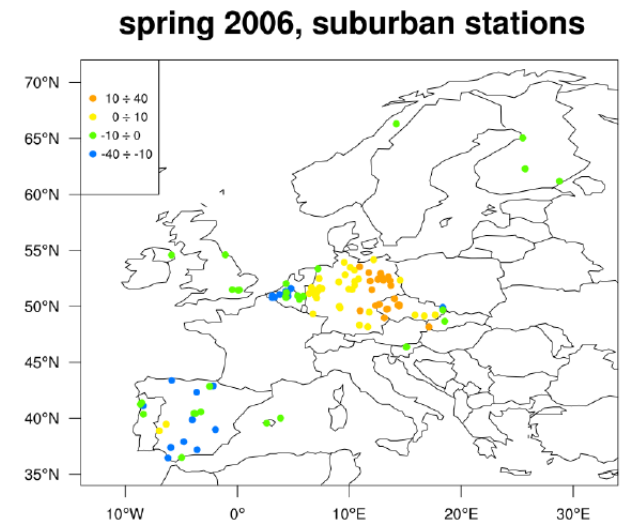

b)

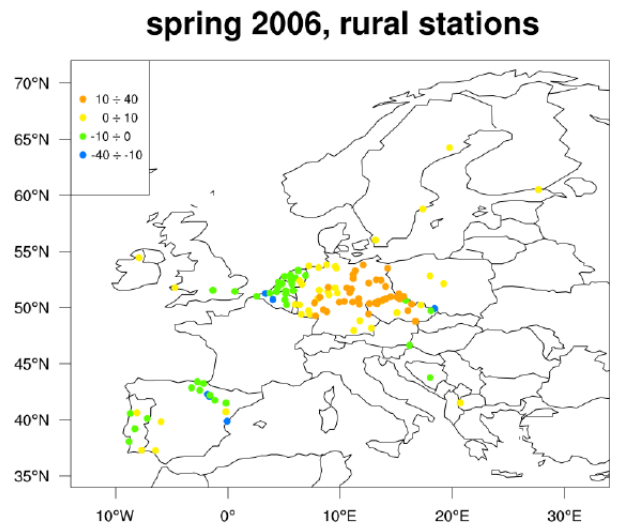

d)

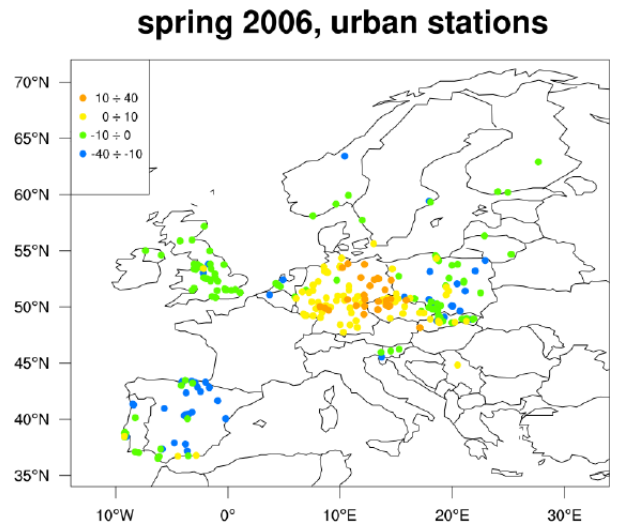

Figure 16. Spring (MAM) $24 \mathrm{~h}$ average $\mathrm{PM}_{10}$ concentrations in $\mu \mathrm{g} \mathrm{m}^{-3}$ (a), MBE at rural stations (b), MBE at suburban stations (c) and MBE at urban stations (d).

els, ozone concentrations at rural stations are reproduced not as well as at suburban and urban stations. This has been confirmed by the GEM-AQ model results. While MAGE is relatively constant (18.2 for rural, 17.2 and 17.4 for suburban and urban respectively), there are significant differences in MBE values for different types of stations.

Analysis of seasonal variability of model performance was undertaken by Nopmongcol et al. (2012) using results from the CAMx model for January and July. Modelled ozone concentrations were systematically underpredicted. CAMx performance was the worst at urban stations in January while in July the bias was lower. Also, Pirovano et al. (2012) reported a strong underestimation of ozone concentrations during the first part of the year for CAMx and CHIMERE models. CMAQ results, described in Appel et al. (2012), indicate that model performance for the daytime ozone varied seasonally. In the winter, CMAQ overestimated ozone con- centration by $8 \%$ and in the spring and summer ozone levels were underestimated on average by $\sim 4$ and $2 \%$ respectively. In autumn model performance was worst, with significant overestimation by $30 \%$. Results from the GEM-AQ model also show seasonality in MBE and the Pearson correlation coefficient. However, MAGE is relatively constant for all seasons - on average $17.5 \pm 0.8 \mu \mathrm{g} \mathrm{m}^{-3}$. For winter and autumn the model slightly overestimated, with MBE 0.93 and $0.09 \mu \mathrm{g} \mathrm{m}^{-3}$ respectively. Although MAGE and MBE are smallest in autumn, the correlation coefficient is lower than in winter (0.78 in autumn, 0.87 in winter). In the spring and summer the model tends to underestimate. However, with nearly the same MAGE, model results for summer are noticeably better with MBE of $1.4 \mu \mathrm{g} \mathrm{m}^{-3}$ and correlation coefficient 0.92 , while in spring the bias is larger at $-3.2 \mu \mathrm{g} \mathrm{m}^{-3}$ and the correlation coefficient is lower at 0.75 . 
a)

GEM-AQ - summer

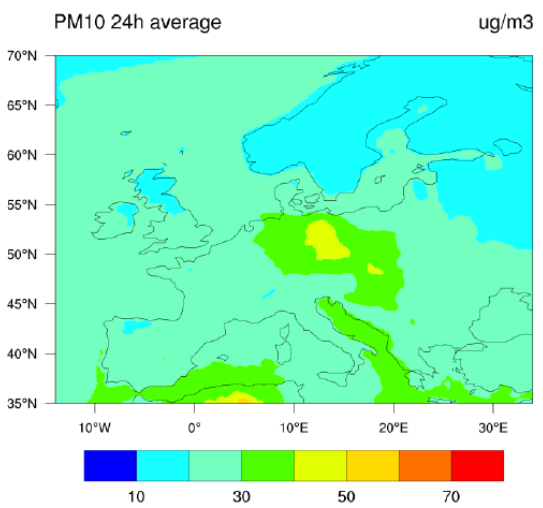

c)

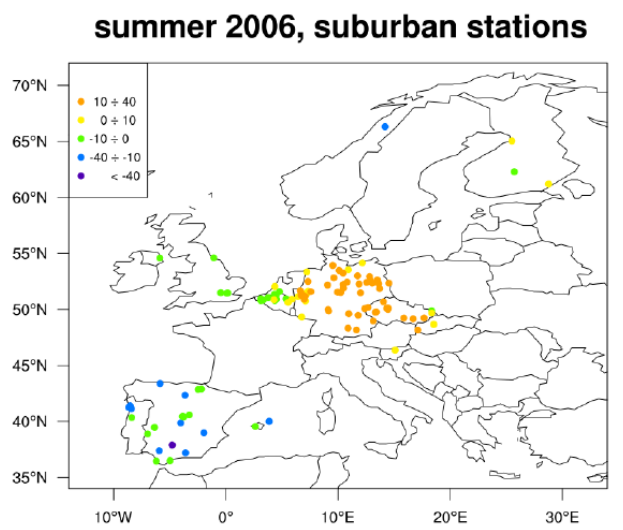

b)

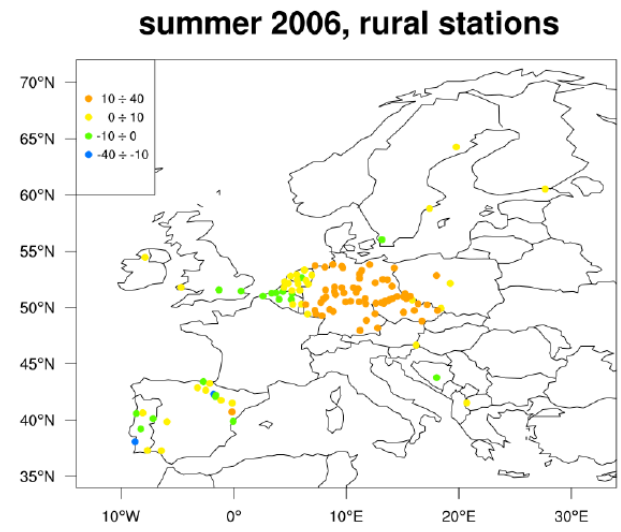

d)

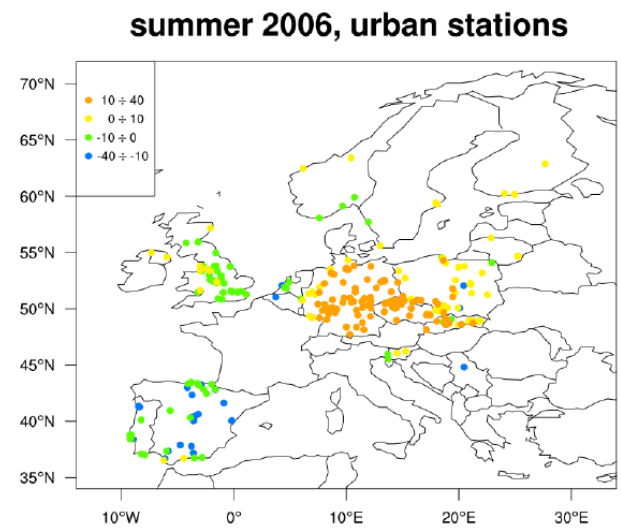

Figure 17. Summer (JJA) $24 \mathrm{~h}$ average $\mathrm{PM}_{10}$ concentrations in $\mu \mathrm{g} \mathrm{m}^{-3}$ (a), MBE at rural stations (b), MBE at suburban stations (c) and MBE at urban stations (d).

Analysis of model performance for different regions showed differences between models. The best performance for CAMx and CHIMERE models (Pirovano et al., 2012) was for southern Europe, while north-western and eastern Europe were characterized with a negative bias in the range of $10-30 \%$, especially in winter. In terms of the correlation coefficient, the CHIMERE model performed well in southern, north-western and eastern Europe, while CAMx showed better results in eastern Europe. The CMAQ model (Appel et al., 2012) overestimated daytime ozone concentrations in the south-western part of the domain and underestimated the north-eastern part, including the British Isles, in winter. The largest overestimation occurred over northern Italy (Po Valley), while the largest underestimation was over the Czech Republic and Poland.

The GEM-AQ model underestimated daytime ozone concentrations; the highest values were found in northern Eu- rope (MBE $-16.8 \mu \mathrm{g} \mathrm{m}^{-3}$ ) especially during the cold part of the year. One possible reason relates to uncertainties of NOx emissions in Scandinavia, as well as over British Isles and the north-western part of Europe, which may contribute to overestimated titration processes in the model. Another source of possible underestimation is too-weak transport of ozone from the upper troposphere in high latitudes. However, such an analysis is beyond the scope of the presented study, which is focused on surface air quality and does not include the analysis of the vertical structure of the atmosphere.

For the rest of the domain the agreement between modelled and observed ozone concentrations is good. However, summer episodes are underestimated. During winter and spring months the MBE distribution shows significant overestimation of ozone concentrations over the Alps, which indicates too intensive downward mixing in the mountain regions, where in the cold part of the year concentrations are 
a)

GEM-AQ - autumn

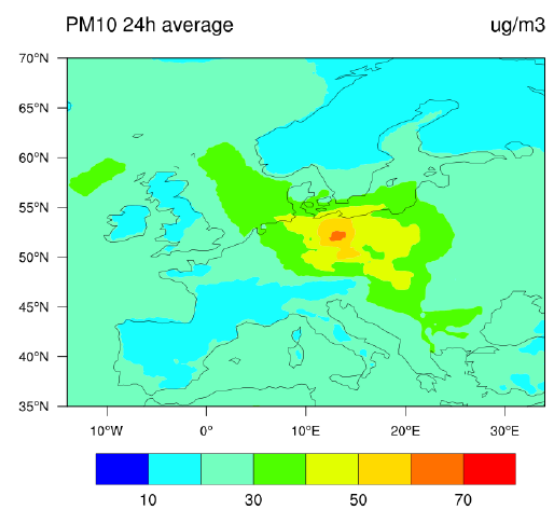

c)

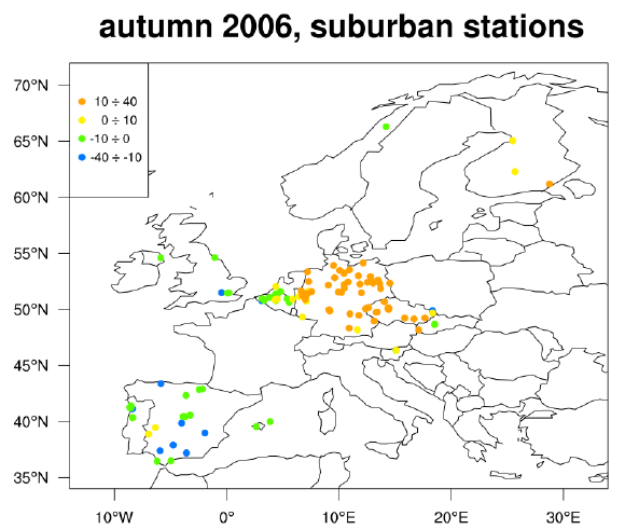

b)

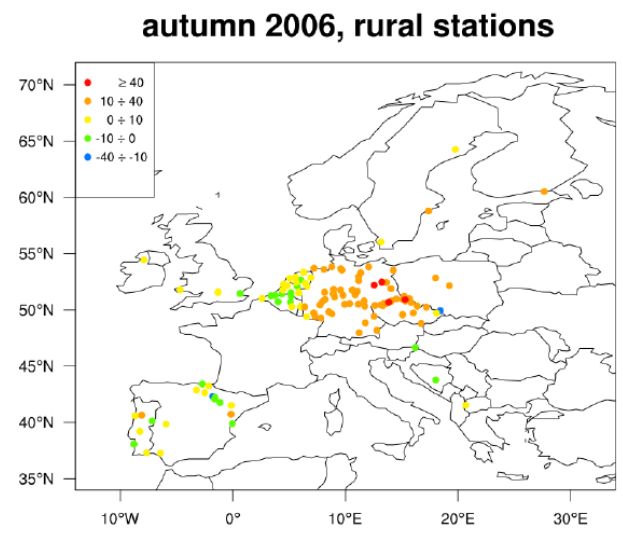

d)

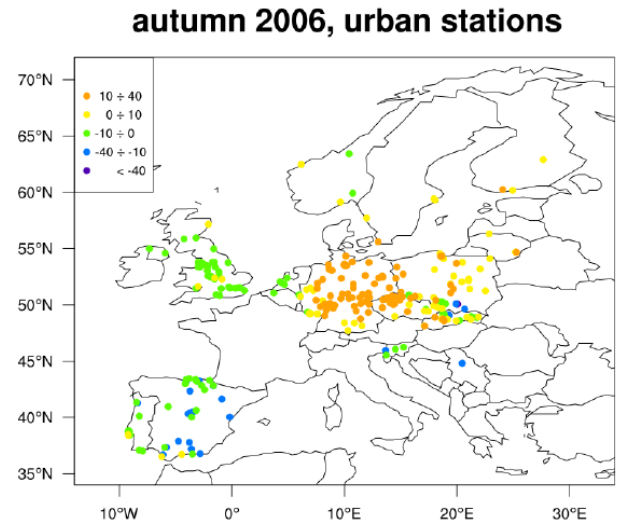

Figure 18. Autumn (SON) $24 \mathrm{~h}$ average $\mathrm{PM}_{10}$ concentrations in $\mu \mathrm{g} \mathrm{m}^{-3}$ (a), $\mathrm{MBE}$ at rural stations (b), MBE at suburban stations (c) and MBE at urban stations (d).

highest. In spring and autumn there is a systematic overestimation for suburban and urban stations in Benelux, Germany and France that results in positive MBE 0.4 for Region II, while for other regions MBE is negative. In general, best model performance was achieved in the summer.

In winter and autumn, topography plays a very important role in the distribution of higher ozone concentration levels, although modelled concentrations seem to be overestimated. Higher concentrations are over the southern part of Europe (with the exception of the Po Valley) and the Mediterranean Sea. In spring, concentrations are significantly higher in southern, central and eastern Europe, while in western Europe and the British Isles the increase is not that significant due to the inflow of relatively clean Atlantic air masses. In summer there is further increase of ozone concentrations over land, with the maximum over Region IV. Elevated ozone concentrations are also over the Mediterranean Sea and the Black Sea. In contrast to ozone distribution patterns in spring, ozone concentrations are lower over north-eastern and eastern Europe. The reason for this effect might confirm the hypothesis of the advective nature of ozone episodes in eastern Europe and the role of high-pressure-system blocks during summer months (Struzewska and Kaminski, 2008). However, due to the lack of measurements, model results cannot be evaluated in this region. In autumn, concentrations decrease to lowest values in the north-eastern part of Europe.

\section{2 $\quad \mathrm{PM}_{10}$}

Surface $\mathrm{PM}_{10}$ concentrations at rural background stations (119 sites) were systematically overestimated in all seasons. In January and February the model captured quite well periods with high $\mathrm{PM}_{10}$ concentrations, but peak values were overestimated. Best model performance was from mid- 

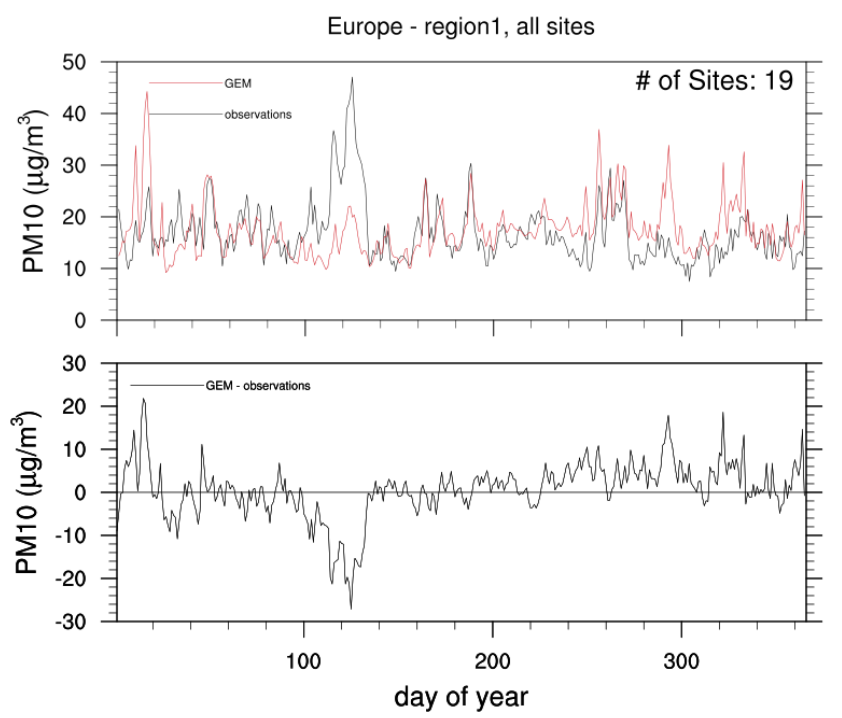

Figure 19. Time series of observed and modelled $\mathrm{PM}_{10} 24 \mathrm{~h}$ concentration averaged for all stations in northern Europe and MBE.

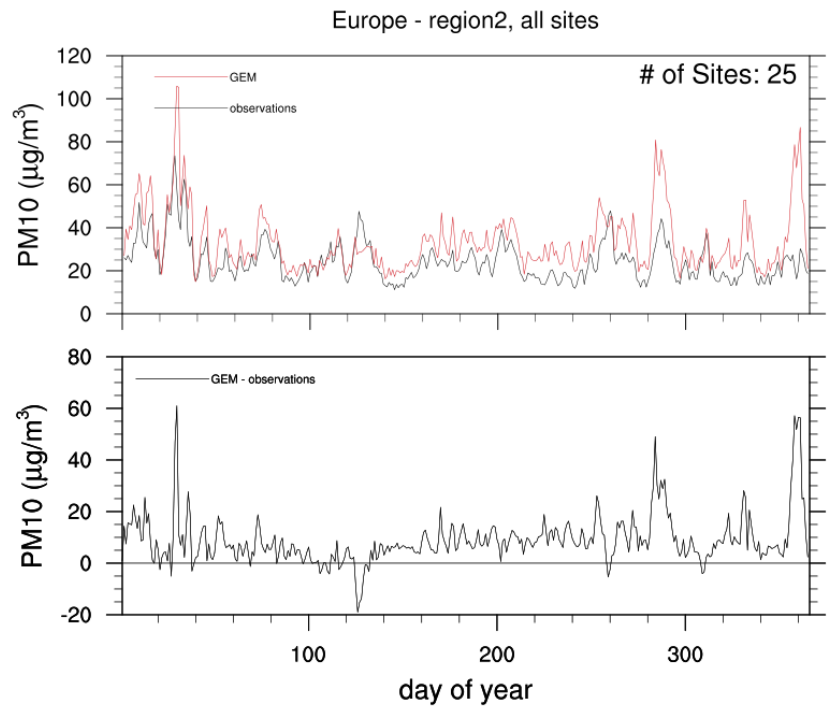

Figure 20. Time series of observed and modelled $\mathrm{PM}_{10} 24 \mathrm{~h}$ concentration averaged for all stations in western Europe and MBE.

February to May. From June to September the systematic bias was relatively constant at $\sim 10-15 \mu \mathrm{g} \mathrm{m}^{-3}$. In autumn, MBE is largest and the model overestimated significantly for all periods with observed higher concentrations. The correlation coefficient is high (0.72): MBE is $10.8 \mu \mathrm{g} \mathrm{m}^{-3}$ and MAGE is $18.2 \mu \mathrm{g} \mathrm{m}^{-3}$ (Table 2).

At suburban stations (110 sites) model performance is very good with MBE $4.7 \mu \mathrm{g} \mathrm{m}^{-3}$ and MAGE $18.4 \mu \mathrm{g} \mathrm{m}^{-3}$. From January to April the agreement of modelled and observed time series, averaged over all suburban stations in the domain, is good except for a short winter episode. At the beginning of May the model underestimated $\mathrm{PM}_{10}$ concentrations
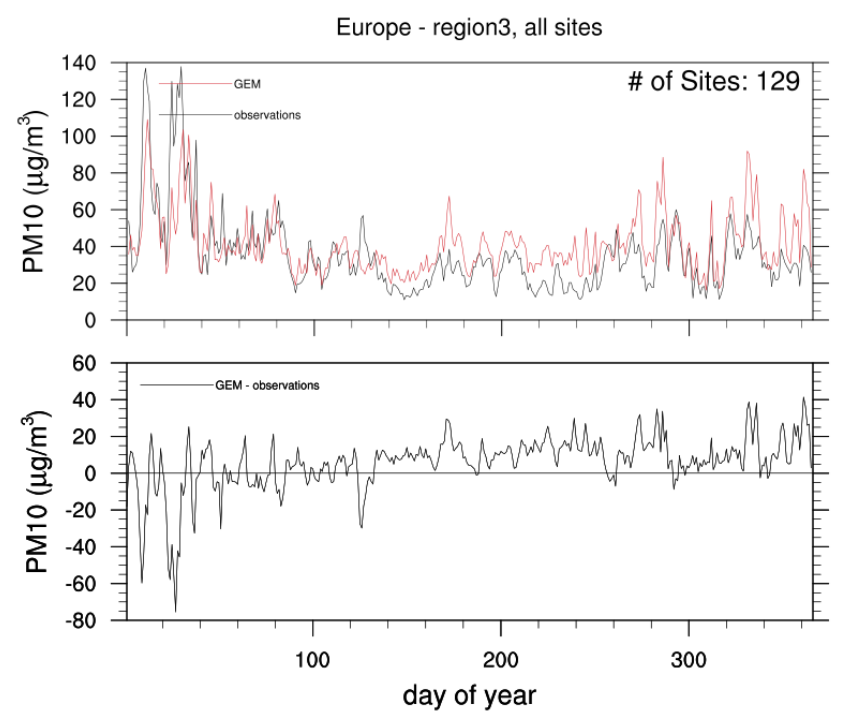

Figure 21. Time series of observed and modelled $\mathrm{PM}_{10} 24 \mathrm{~h}$ concentration averaged for all stations in central Europe and MBE.

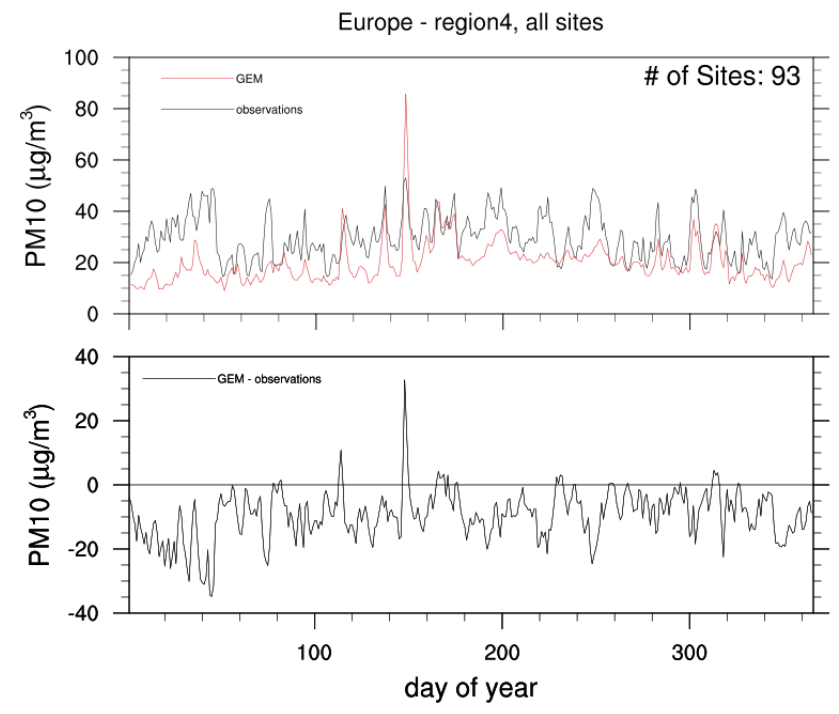

Figure 22. Time series of observed and modelled $\mathrm{PM}_{10} 24 \mathrm{~h}$ concentration averaged for all stations in southern Europe and MBE.

by about 10 to $20 \mu \mathrm{g} \mathrm{m}^{-3}$. From June to September, modelled and observed concentrations at suburban stations averaged over the domain vary in the range of $20-40 \mu \mathrm{g} \mathrm{m}^{-3}$. There is a small systematic overestimation of modelled $\mathrm{PM}_{10}$ - on average $5 \mu \mathrm{g} \mathrm{m}^{-3}$. As in the case of rural stations, starting in October the discrepancies between model and measurements increase. The model generated three $\mathrm{PM}_{10}$ episodes from October to December which were not observed. In spite of discrepancies, the correlation coefficient is relatively high (0.75), which confirms good agreement in terms of average concentration level and short-term variability. 
Table 1. Error statistics for GEM-AQ model performance - maximum $8 \mathrm{~h}$ running average of ozone concentrations in $\mu \mathrm{g} \mathrm{m}^{-3}$.

\begin{tabular}{lrrr}
\hline & MBE & MAGE & Correlation \\
\hline All stations & -0.9 & 17.6 & 0.93 \\
Seasonal: & & & \\
Winter & -0.8 & 17.6 & 0.71 \\
Spring & 0.3 & 18.0 & 0.66 \\
Summer & -6.7 & 17.7 & 0.96 \\
Autumn & 3.6 & 17.1 & 0.93 \\
Station type: & & & \\
Rural & -7.0 & 18.2 & 0.92 \\
Suburban & 1.9 & 17.2 & 0.93 \\
Urban & 2.5 & 17.4 & 0.93 \\
Regions: & & & \\
Region I & -16.8 & 20.7 & 0.83 \\
Region II & 0.4 & 16.5 & 0.91 \\
Region III & -1.5 & 17.6 & 0.89 \\
Region IV & -1.4 & 19.9 & 0.96 \\
\hline
\end{tabular}

For urban stations (263 sites) the agreement between modelled and observed $\mathrm{PM}_{10}$ concentration levels is good. MAGE is comparable to the value obtained for suburban stations $\left(18.3 \mu \mathrm{g} \mathrm{m}^{-3}\right)$, MBE is small $\left(1.3 \mu \mathrm{g} \mathrm{m}^{-3}\right)$ and the correlation coefficient is 0.72 . The model underestimates observed $\mathrm{PM}_{10}$ concentration during two severe pollution episodes at urban stations in January and at the beginning of February. From the second week of February concentrations decrease and the agreement between modelled and observed daily average $\mathrm{PM}_{10}$ levels was good. In May the model did not capture an increase of $\mathrm{PM}_{10}$ concentrations. From June to September the model tends to overestimate $\mathrm{PM}_{10}$ levels by 5 to $10 \mu \mathrm{g} \mathrm{m}^{-3}$. In October and December the model showed significant overestimation, while in November the agreement was good.

Daily mean $\mathrm{PM}_{10}$ concentrations averaged over suburban and urban stations show good agreement of the modelled and observed concentrations averaged over the domain for values below $40 \mu \mathrm{g} \mathrm{m}^{-3}$. At suburban stations, modelled $\mathrm{PM}_{10}$ concentrations in the range of 60 to $100 \mu \mathrm{g} \mathrm{m}^{-3}$ were overestimated, while for urban stations the highest concentrations, above $60 \mu \mathrm{g} \mathrm{m}^{-3}$, were underestimated.

In contrast to the GEM-AQ model results, Solazzo et al. (2012a) reported that most models used in their analyses had difficulties in reproducing elevated PM concentrations during winter. Most models underestimated $\mathrm{PM}_{10}$ levels over Europe, although during summer the performance was better. In the Mediterranean region, the highest concentrations were in summer months. Results from the CAMx model (Nopmongcol et al., 2012) were substantially underestimated and performance was poor for both January and July, with similar magnitude of error statistics. Also, the DEHM model (Brandt et al., 2012) underestimated $\mathrm{PM}_{10}$ concentrations.
Table 2. Error statistics for GEM-AQ model performance - $24 \mathrm{~h}$ running average of $\mathrm{PM}_{10}$ concentrations in $\mu \mathrm{g} \mathrm{m}^{-3}$.

\begin{tabular}{lrrr}
\hline & MBE & MAGE & Correlation \\
\hline All stations & 4.3 & 18.3 & 0.74 \\
Seasonal: & & & \\
Winter & 3.4 & 24.4 & 0.74 \\
Spring & 0.2 & 15.0 & 0.71 \\
Summer & 6.3 & 15.7 & 0.81 \\
Autumn & 7.4 & 18.3 & 0.8 \\
Station type: & & & \\
Rural & 10.8 & 18.2 & 0.72 \\
Suburban & 4.7 & 18.4 & 0.75 \\
Urban & 1.3 & 18.3 & 0.72 \\
Regions: & & & \\
Region I & 0.6 & 10.3 & 0.32 \\
Region II & 8.9 & 16.7 & 0.73 \\
Region III & 5.9 & 24.2 & 0.72 \\
Region IV & -9.4 & 16.2 & 0.56 \\
\hline
\end{tabular}

The GEM-AQ model tends to overestimate $\mathrm{PM}_{10}$ daily mean concentrations. The model performance is clearly better for urban stations. With nearly the same MAGE, 18.3 \pm $8 \mu \mathrm{g} \mathrm{m}^{-3}$, the highest overestimation was for rural background stations, $10.8 \mu \mathrm{g} \mathrm{m}^{-3}$. For suburban and urban stations the performance is better -4.7 and $1.3 \mu \mathrm{g} \mathrm{m}^{-3}$ - and the correlation coefficients are 0.72 and 0.75 respectively.

The work by Pirovano et al. (2012) shows that the best performance of CAMx and CHIMERE models in terms of $\mathrm{PM}_{10}$ concentrations was in north-western Europe for ruralbackground stations. In southern and eastern Europe, model results were underestimated. Appel et al. (2012) reported that in winter the domain-averaged MBE is $-21.5 \mu \mathrm{g} \mathrm{m}^{-3}$ for the CMAQ model. For other seasons the underestimation is lower - in the range of $-11 /-16 \mu \mathrm{g} \mathrm{m}^{-3}$. The smallest bias was in northern France. In spring and summer the bias spatial pattern was similar to the winter case and the bias tends to improve in autumn.

In southern Europe, modelled concentrations were systematically underestimated for all seasons with the bias $-9.41 \mu \mathrm{g} \mathrm{m}^{-3}$. However, for other regions GEM-AQ tends to overestimate $\mathrm{PM}_{10}$ daily mean concentrations. In winter in northern and western Europe the model overestimates, while in central and eastern Europe there was a strong underestimation. These lead to error compensation in terms of averaged MBE $\left(0.3 \mu \mathrm{g} \mathrm{m}^{-3}\right)$ for winter months and a relatively high MAGE of $22.5 \mu \mathrm{g} \mathrm{m}^{-3}$. In the spring model performance is the best in terms of MBE $\left(1.9 \mu \mathrm{g} \mathrm{m}^{-3}\right)$ and MAGE $\left(14.8 \mathrm{\mu g} \mathrm{m}^{-3}\right)$, but the correlation coefficient is lower than in other seasons (0.51). In autumn, the model overestimated over all regions but the correlation coefficient is relatively high (0.79). The worst performance in terms of correlation coefficient was over northern Europe (0.32) and southern Europe $(0.56)$. 
The distribution of MBEs for $\mathrm{PM}_{10}$ clearly shows that anthropogenic emission data were overestimated over Germany and the Czech Republic. MBE in this region (especially over the eastern part of Germany) was positive for all types of stations and for all seasons. This impacted the average model bias in Region II. In Region III modelled $\mathrm{PM}_{10}$ concentrations were underestimated during severe winter pollution episodes in January and February 2006. During this period, low temperatures were observed and differences between modelled and observed $\mathrm{PM}_{10}$ levels might be caused by toolow emission estimates that did not account for household heating. In addition, as the lowest model layer height is at $\sim 27 \mathrm{~m}$, the structure of the stable boundary layer over urban regions might not be fully reproduced. Underestimation of $\mathrm{PM}_{10}$ in southern Europe is most probably due to underestimated mineral dust emissions and transport from North Africa. However, this does not relate to AQMEII emission estimates but to an online dust emission module (Marticorena et al., 1995) in the GEM-AQ model. Further work will be undertaken to revise geophysical fields describing soil properties that are used for dust uptake. The highest error was for rural stations, which clearly indicates that emissions in remote regions were overestimated. For urban stations in January, February and March the model systematically underestimated $\mathrm{PM}_{10}$ concentrations. The temporal variability of MBE for different types of stations is similar.

Seasonal variability of $\mathrm{PM}_{10}$ concentrations is dominated by the distribution and intensity of anthropogenic and natural sources. In winter, $\mathrm{PM}_{10}$ concentrations are highest over central and eastern Europe, although the model tends to overestimate over Germany. Also, elevated concentrations are present over the Northern Atlantic due to sea salt generation during winter storms. In spring, the winter maximum over the Atlantic dissipates and concentration over North Africa and southern Europe is increasing. The highest concentrations remain over central Europe. A similar pattern was calculated for summer months, with lower maximum but higher background values. In autumn, $\mathrm{PM}_{10}$ concentrations over the Atlantic Ocean and over the North Sea increase and over southern Europe decrease. In eastern Europe, $\mathrm{PM}_{10}$ background concentrations are also higher than in spring and summer months.

\section{Summary and conclusions}

In the scope of AQMEII Phase 1, the GEM-AQ model was run over Europe for the year 2006. The modelling domain was defined using a global variable resolution grid with a rotated equator. The uniform part of the domain with resolution of $0.2^{\circ} \times 0.2^{\circ}$ was positioned over the European continent.

Modelled concentrations for ozone maximum $8 \mathrm{~h}$ running average and daily mean $\mathrm{PM}_{10}$ were analysed in terms of spatial distribution and temporal variability. Model results were evaluated against measurements available in the EN-
SEMBLE database. For better understanding of the model performance in terms of station representativeness, emission estimates and climate characteristics, the concentration data were averaged for

- all stations in the domain for the whole year and for each season (DJF/MAM/JJA/SON)

- different types of stations (rural/suburban/urban)

- four climatic regions of Europe.

In summary,

1. For ozone, values of the mean absolute gross error and the Pearson correlation coefficient are similar for all station types. However, differences in the mean bias error are significant. The best performance (MBE $1.9 \mu \mathrm{g} \mathrm{m}^{-3}$ ) for ozone was obtained for suburban locations and slightly higher overestimation (MBE $2.5 \mu \mathrm{g} \mathrm{m}^{-3}$ ) was calculated for urban sites. The worst performance was obtained for rural stations where the model tends to underestimate (MBE $-7.0 \mu \mathrm{g} \mathrm{m}^{-3}$ ).

2. For $\mathrm{PM}_{10}$, values of the mean absolute gross error and the Pearson correlation coefficient are similar for all station types. However, differences in the mean bias error are significant. The best results were modelled for urban stations (MBE $1.3 \mu \mathrm{g} \mathrm{m}^{-3}$ ), while over most of Europe concentrations at rural sites were overestimated (MBE $10.8 \mu \mathrm{g} \mathrm{m}^{-3}$ ) by the model.

3. Although the representativeness of urban stations for model results at the resolution of $20 \mathrm{~km}$ may seem questionable, the model performance was worst for rural stations for both analysed species. This may indicate that the emission estimates in rural areas are less accurate and smaller than in cities. Perhaps emission accuracy influences model performance more significantly than the sub-grid local features of the emission field.

4. A possible explanation for the systematic underestimation of ozone concentrations over Scandinavia and the Baltic Sea could be an insufficient transport of ozone from the upper troposphere or errors in emission estimates over the Baltic Sea and the North Sea. These hypotheses require further investigation.

5. The largest systematic differences among the GEM-AQ model performances for different types of stations were from January to March and in December, when ozone levels depend to a large extent on dynamical factors. During the summer months, when photochemical production dominates, the model performance for different types of stations is comparable.

6. In regions where the monitoring network is sufficiently dense, errors in emission inventories can be linked to er- 
rors in modelling results with greater confidence. Systematic overestimation of $\mathrm{PM}_{10}$ concentrations indicates that anthropogenic emissions are overestimated over Germany and the Czech Republic. Limited availability of $\mathrm{PM}_{10}$ measurements in Scandinavia and a lack of data for France, Italy and eastern European countries do not allow evaluation of emission uncertainties in these regions. The overestimation of ozone concentrations in industrial regions of western Europe in spring and autumn indicates high uncertainty of $\mathrm{NO}_{\mathrm{x}}$ emission estimation in this region, at least in terms of annual temporal variability.

7. Seasonal differences among distribution patterns of the concentration fields relate to large-scale dynamics. Elevated ozone concentrations during autumn and winter are calculated for mountain regions as a result of the transport from the upper troposphere in the model. In spring and summer, photochemical production dominates and highest concentrations are calculated over regions characterized with highest emissions. $\mathrm{PM}_{10}$ concentration patterns correspond to the distribution of anthropogenic emissions. Also, changes in the wind field that drive natural emissions (sea salt, dust) play an important role.

8. The highest discrepancies between modelled and observed concentrations are for periods characterized with highest concentration levels (ozone in summer, $\mathrm{PM}_{10}$ in winter).

9. Modelled ozone distribution patterns over north-eastern and eastern Europe show lower concentrations in the summer than in the spring. The reason for this effect might confirm the hypothesis of advective nature of ozone episodes in eastern Europe and the role of highpressure-system blocks during summer months

In conclusion, spatial distribution and seasonal variability of air pollution species depend on regional climate and are strongly modulated by anthropogenic emission fluxes. Although "climatology of air pollution species" may not coincide with climate classifications for Europe, the presented analyses confirm that interpretation of modelling results is enhanced when regional climate characteristics are taken into consideration. Thus, data stratification should be recommended for model analysis and evaluation methodology.

Acknowledgements. This study was sponsored by the Polish Ministry of Science and Higher Education grant $821 / \mathrm{N}$ AQMEII/2010/0 (Identification of atmospheric pollutants transformation mechanisms in regional-scale modelling). J. W. Kaminski was partially supported by the Canadian Foundation for Climate and Atmospheric Sciences. The AQMEII community (http://aqmeii.jrc.ec.europa.eu/) is kindly acknowledged for providing observational data.
Edited by: A. Dastoor

\section{References}

Appel, K. W., Chemel, C., Roselle, S. J., Francis, X. V., Hu, R.-M., Sokhi, R. S., Rao, S. T., and Galmarini, S.: Examination of the Community Multiscale Air Quality (CMAQ) model performance over the North American and European domains, Atmos. Environ., 53, 142-155, doi:10.1016/j.atmosenv.2011.11.016, 2012.

Bélair, S., Mailhot, J., Girard, C., and Vaillancourt, P.: Boundary Layer and Shallow Cumulus Clouds in a Medium-Range Forecast of a Large-Scale Weather System, Mon. Weather Rev., 133, 1938-1960, 2005.

Bougeault, P. and Lacarrere, P.: Parameterization of orographyinduced turbulence in a mesobeta-scale model, Mon. Weather Rev., 117, 1872-1890, 1989.

Brandt, J., Silver, J. D., Frohn, L. M., Geels, C., Gross, A., Hansen, A. B., Hansen, K. M., Hedegaard, G. B., Skjøth, C. A., Villadsen, H., Zare, A., and Christensen, J. H.: An integrated model study for Europe and North America using the Danish Eulerian Hemispheric Model with focus on intercontinental transport of air pollution, Atmos. Environ., 53, 156-176, doi:10.1016/j.atmosenv.2012.01.011, 2012.

Côté, J., Gravel, S., Méthot, A., Patoine, A., Roch, M., and Staniforth, A.: The operational CMC-MRB Global Environmental Multiscale (GEM) Model. Part I: Design considerations and formulation, Mon. Weather Rev., 126, 1373-1395, 1998a.

Côté, J., Desmarais, J.-G., Gravel, S., Méthot, A., Patoine, A., Roch, M., and Staniforth, A.: The Operational CMC-MRB Global Environmental Multiscale (GEM) Model. Part II: Results, Mon. Weather Rev., 126, 1397-1418, 1998b.

Deardorff, J. W.: Efficient prediction of ground surface temperature and moisture with inclusion of a layer of vegetation, J. Geophys. Res., 83, 1889-1903, 1978.

Dennis, R., Fox, T., Fuentes, M., Gilliland, A., Hanna, S., Hogrefe, C., Irwin, J., Rao, S. T., Scheffe, R., Schere, K., Steyn, D., and Venkatram, A.: A framework for evaluating regional-scale numerical photochemical modeling systems, Environ. Fluid Mech., 10, 471-489, 2010.

Fouquart, Y. and Bonnel, B.: Computations of solar heating of the earth's atmosphere: A new parameterization, Contrib. Atmos. Phys., 53, 35-62, 1980.

Galmarini, S., Bianconi, R., Bellasio, R., and Graziani, G.: Forecasting the consequences of accidental releases of radionuclides in the atmosphere from ensemble dispersion modelling. J. Environ. Radioactiv., 57, 203-219, 2001.

Galmarini, S., Bianconi, R., Klug, W., Addis, R., Andronopoulos, S., Baklanov, A., Bartniki, J., Bartzis, J. C., Bellasio, R., Bompay, F., Buckley, R., Bouzom, M., Champion, H., D'Amours, R., Davakis, E., Eleveld, H., Geertsema, G. T., Glaab, H., Kollax, M., Ilvonen, M., Manning, A., Pechinger, U., Persson, C., Polreich, E., Potemski, S., Prodanova, M., Saltbones, J., Slaper, H., Sofiev, M. A., Syrakov, D., Sørensen, J. H., Auwera, Van der, L., Valkama, I., and Zelazny, R.: Ensemble dispersion forecasting, Part 1: Concept, approach and indicators, Atmos. Environ., 38, 4607-4617, doi:10.1016/j.atmosenv.2004.05.030, 2004. 
Galmarini, S., Rao, S. T., and Steyn, D. G.: AQMEII: An international initiative for the evaluation of regional-scale air quality models - Phase 1 Preface, Atmos. Environ., 53, 1-3, 2012.

Garand, L.: Some improvements and complements to the infrared emissivity algorithm including a parameterization of the absorption in the continuum region, J. Atmos. Sci., 40, 230-244, 1983.

Gauthier, P., Charette, C., Fillion, L., Koclas, P., and Laroche, S.: Implementation of a 3-D assimilation system at the Canadian Meteorological Centre. Part I: The global analysis, Atmos. Ocean, 37, 103-156, 1999.

Gong, S. L., Barrie, L. A., Blanchet, J.-P., Salzen, K. v., Lohmann, U., Lesins, G., Spacek, L., Zhang, L. M., Girard, E., Lin, H., Leaitch, R., Leighton, H., Chylek, P., and Huang, P.: Canadian aerosol module: A size-segregated simulation of atmospheric aerosol processes for climate and air quality models 1. Module development, J. Geophys. Res., 108, 4007, doi:10.1029/2001JD002002, 2003.

Gong, S. L., Lavoué, D., Zhao, T. L., Huang, P., and Kaminski, J. W.: GEM-AQ/EC, an on-line global multi-scale chemical weather modelling system: model development and evaluation of global aerosol climatology, Atmos. Chem. Phys., 12, 8237-8256, doi:10.5194/acp-12-8237-2012, 2012.

Hogrefe, C., Roselle, S., Mathur, R., Rao, S. T., Galmarini, S.: Space-time analysis of the Air Quality Model Evaluation International Initiative (AQMEII) Phase 1 air quality simulations, J. Air Waste Manage., 64, 388-405, doi:10.1080/10962247.2013.811127, 2013.

Kain, J. S. and Fritsch, J. M.: A one-dimensional entraining/detraining plume model and its application in convective parameterization, J. Atmos. Sci., 47, 2784-2802, 1990.

Kain, J. S. and Fritsch, J. M.: Convective parameterization for mesoscale models: The Kain-Fritsch scheme. The representation of cumulus convection in numerical models. Meteor. Monogr., No. 24, Amer. Meteor. Soc., 165-170, 1993.

Kaminski, J. W., Neary, L., Struzewska, J., McConnell, J. C., Lupu, A., Jarosz, J., Toyota, K., Gong, S. L., Côté, J., Liu, X., Chance, K., and Richter, A.: GEM-AQ, an on-line global multiscale chemical weather modelling system: model description and evaluation of gas phase chemistry processes, Atmos. Chem. Phys., 8, 3255-3281, doi:10.5194/acp-8-3255-2008, 2008.

Lurmann, F. W., Lloyd, A. C., and Atkinson, R.: A chemical mechanism for use in long-range transport/acid deposition computer modeling, J. Geophys. Res., 91, 10905-10936, 1986.

Mailhot, J., Bélair, S., Lefaivre, L., Bilodeau, B., Desgagné, M., Girard, C., Glazer, A., Leduc, A., Méthot, A., Patoine, A., Plante, A., Rahill, A., Robinson, T., Talbot, D., Tremblay, A., Vaillancourt, P., Zadra, A., and Qaddouri, A.: The $15 \mathrm{~km}$ version of the Canadian regional forecast system, Atmos. Ocean, 44, 133-149, 2006.

Marticorena, B. and Bergametti, G.: Modeling the atmospheric dust cycle: 1. Design of a soil-derived dust emission scheme, J. Geophys. Res., 100, 16415-16430, doi:10.1029/95JD00690, 1995

McFarlane, N. A.: The effect of orographically excited gravity wave drag on the general circulation of the lower stratosphere and troposphere, J. Atmos. Sci., 44, 1775-1800, 1987.

McLandress, C. and McFarlane, N. A.: Interactions between orographic gravity wave drag and forced stationary planetary waves in the winter Northern Hemisphere middle atmosphere, J. Atmos. Sci., 50, 1966-1990, 1993.
Nopmongcol, U., Koo, B., Tai, E., Jung, J., Piyachaturawat, P., Emery, C., Yarwood, G., Pirovano, G., Mitsakou, C., and Kallos, G.: Modeling europe with CAMx for the Air Quality Model Evaluation International Initiative (AQMEII), Atmos. Environ., 53, 177-185, doi:10.1016/j.atmosenv.2011.11.023, 2012.

Olivier, J. G. J. and Berdowski, J. J. M.: Global emissions sources and sinks, in: The Climate System, edited by: Guicherit, R., and Heij, B., 33-78, A.A. Balkema Publishers/Swets and Zeitlinger Publishers, Lisse, the Netherlands, 2001.

Olivier, J. G. J., Bouwman, A. F., Berdowski, J. J. M., Veldt, C., Bloos, J. P. J., Visschedijk, A. J. H., van der Maas, C. W. M., and Zandveld, P. Y. J.: Sectoral emission inventories of greenhouse gases for 1990 on a per country basis as well as on $1^{\circ} \times 1^{\circ}$, Environ. Sci. Policy, 2, 241-263, 1999.

Pirovano, G., Balzarini, A., Bessagnet, B., Emery, C., Kallos, G., Meleux, F., Mitsakou, C., Nopmongcol, U., Riva, G. M., and Yarwood, G.: Investigating impacts of chemistry and transport model formulation on model performance at European scale, Atmos. Environ., 53, 93-109, doi:10.1016/j.atmosenv.2011.12.052, 2012.

Pouliot, G., Pierce, T., Denier van der Gon, H., Schaap, M., Moran, M., and Nopmongcol, U.: Comparing emission inventories and model-ready emission datasets between Europe and North America for the AQMEII project, Atmos. Environ., 53, 414, 2012.

Putaud, J. P., Van Dingenen, R., Alastuey, A., Bauer, H., Birmili, W., Cyrys, J., Flentje, H., Fuzzi, S., Gehrig, R., Hansson, H. C., Harrison, R. M., Herrmann, H., Hitzenberger, R., Hüglin, C., Jones, A. M., Kasper-Giebl, A., Kiss, G., Kousa, A., Kuhlbusch, T. A. J., Löschau, G., Maenhaut, W., Molnar, A., Moreno, T., Pekkanen, J., Perrino, C., Pitz, M., Puxbaum, H., Querol, X., Rodriguez, S., Salma, I., Schwarz, J., Smolik, J., Schneider, J., Spindler, G., ten Brink, H., Tursic, J., Viana, M., Wiedensohler, A., and Raes, F.: A European aerosol phenomenology - 3: physical and chemical characteristics of particulate matter from 60 rural, urban, and kerbside sites across Europe. Atmos. Environ., 44, 1352-2310, doi:10.1016/j.atmosenv.2009.12.011, 2010.

Robert, A., Yee, T. L. and Ritchie, H.: A Semi-Lagrangian and Semi-Implicit Numerical Integration Scheme for Multilevel Atmospheric Models. Mon. Wea. Rev., 113, 388-394, doi:10.1175/1520-0493(1985)113<0388:ASLASI>2.0.CO;2, 1985.

Solazzo, E., Bianconi, R., Pirovano, G., Matthias, V., Vautard, R., Moran, M. D., Appel, K. W., Bessagnet, B., Brandt, J., Christensen, J. H., Chemel, C., Coll, I., Ferreira, J., Forkel, R., Francis, X. V., Grell, G., Grossi, P., Hansen, A. B., Miranda, A. I., Nopmongcol, U., Prank, M., Sartelet, K. N., Schaap, M., Silver, J. D., Sokhi, R. S., Vira, J., Werhahn, J., Wolke, R., Yarwood, G., Zhang, J., Rao, S. T., and Galmarini, S.: Operational model evaluation for particulate matter in Europe and North America in the context of AQMEII, Atmos. Environ., 53, 75-92, doi:10.1016/j.atmosenv.2012.02.045, 2012a.

Solazzo, E., Bianconi, R., Vautard, R., Appel, K. W., Moran, M. D., Hogrefe, C., Bessagnet, B., Brandt, J., Christensen, J. H., Chemel, C., Coll, I., Van der Gon, H. D., Ferreira, J., Forkel, R., Francis, X. V., Grell, G., Grossi, P., Hansen, A. B., Jericevic, A., Kraljevic, L., Miranda, A. I., Nopmongcol, U., Pirovano, G., Prank, M., Riccio, A., Sartelet, K. N., Schaap, M., Silver, J. D., 
Sokhi, R. S., Vira, J., Werhahn, J., Wolke, R., Yarwood, G., Zhang, J., Rao, S. T., and Galmarini, S.: Model evaluation and ensemble modelling of surface-level ozone in Europe and North America in the context of AQMEII, Atmos. Environ., 53, 60-74, 2012b.

Solazzo, E., Riccio, A., Kioutsioukis, I., and Galmarini, S.: Pauci ex tanto numero: reduce redundancy in multi-model ensembles, Atmos. Chem. Phys., 13, 8315-8333, doi:10.5194/acp-13-83152013, 2013.

Struzewska, J. and Kaminski, J. W.: Formation and transport of photooxidants over Europe during the July 2006 heat wave - observations and GEM-AQ model simulations. Atmos. Chem. Phys., 8, 721-736, doi:10.5194/acp-8-721-2008, 2008.
Sundqvist, H.: A parameterization scheme for non-convective condensation including prediction of cloud water content, Q. J. Roy. Meteor. Soc., 104, 677-690, 1978.

Tagaris, E., Sotiropoulou, R. E. P., Gounaris, N., Andronopoulos, S., and Vlachogiannis, D.: Air quality over Europe: modelling gaseous and particulate pollutants, Atmos. Chem. Phys., 13, 9661-9673, doi:10.5194/acp-13-9661-2013, 2013.

Venkatram, A., Karamchandani, P. K., and Misra, P. K.: Testing a comprehensive acid deposition model, Atmos. Environ., 22, 737-747, 1988. 